\title{
Biochemistry of Amyloid $\beta$-Protein and Amyloid Deposits in Alzheimer Disease
}

\author{
Colin L. Masters ${ }^{1}$ and Dennis J. Selkoe ${ }^{2}$ \\ ${ }^{1}$ The Mental Health Research Institute, The University of Melbourne, Parkville 3010, Australia \\ ${ }^{2}$ Center for Neurologic Diseases, Harvard Medical School and Brigham and Women's Hospital, Boston, \\ Massachusetts 02115 \\ Correspondence: c.masters@unimelb.edu.au
}

\begin{abstract}
Progressive cerebral deposition of the amyloid $\beta$-protein $(A \beta)$ in brain regions serving memory and cognition is an invariant and defining feature of Alzheimer disease. A highly similar but less robust process accompanies brain aging in many nondemented humans, lower primates, and some other mammals. The discovery of $A \beta$ as the subunit of the amyloid fibrils in meningocerebral blood vessels and parenchymal plaques has led to innumerable studies of its biochemistry and potential cytotoxic properties. Here we will review the discovery of $A \beta$, numerous aspects of its complex biochemistry, and current attempts to understand how a range of $A \beta$ assemblies, including soluble oligomers and insoluble fibrils, may precipitate and promote neuronal and glial alterations that underlie the development of dementia. Although the role of $A \beta$ as a key molecular factor in the etiology of Alzheimer disease remains controversial, clinical trials of amyloid-lowering agents, reviewed elsewhere in this book, are poised to resolve the question of its pathogenic primacy.
\end{abstract}

\section{THE LASTING IMPACT OF THE DISCOVERY OF AMYLOID $\beta$-PROTEIN ON THE ELUCIDATION OF ALZHEIMER DISEASE}

W ith the benefit of hindsight, it is now clear that the isolation and partial sequencing of the meningovascular amyloid $\beta$-protein $(\mathrm{A} \beta)$ by George Glenner and Caine Wong in 1984 provided a turning point for modern research on the fundamental mechanism of Alzheimer disease (AD). Ever since Alzheimer peered through the microscope at the brain of his first patient and wrote prophetically "scattered through the entire cortex ... one found miliary foci that were caused by the deposition of a peculiar substance ...," neuropathologists had sought the nature of the amyloid material found in the senile plaque. By the early 1980s, as compositional analyses of the neurofibrillary tangle were beginning (see Mandelkow and Mandelkow 2011), a few investigators turned their attention to the identity of the amyloid protein in vascular and plaque deposits. In this chapter, we will review how our biochemical understanding of the amyloid deposits emerged and has advanced, and we will describe many features of the peptides that comprise this hallmark lesion of $\mathrm{AD}$ and certain molecules associated with them. The trafficking and proteolytic processing of amyloid precursor protein (APP), including the generation of

Editors: Dennis J. Selkoe, Eckhard Mandelkow, and David M. Holtzman

Additional Perspectives on The Biology of Alzheimer Disease available at www.perspectivesinmedicine.org

Copyright (C) 2012 Cold Spring Harbor Laboratory Press; all rights reserved; doi: 10.1101/cshperspect.a006262

Cite this article as Cold Spring Harb Perspect Med 2012;2:a006262 
$A \beta$, and the proteolytic degradation of the peptide are covered in other chapters (see Haass et al. 2011; Saido and Leissring 2011, respectively) and will not be discussed here.

\section{BIOCHEMISTRY OF A $\beta$ IN MENINGOVASCULAR AMYLOID DEPOSITS AND AMYLOID PLAQUE CORES}

Because George Glenner's earlier research on the circulating precursors of nonneural amyloid deposits (e.g., AL amyloid) convinced him that the amyloid in $\mathrm{AD}$ might well be derived from a serum precursor, he focused his attention on the amyloid in meningeal vessel walls. By stripping the meninges from postmortem AD brains, Glenner and Wong enriched for amyloid-bearing microvessels and discarded the cerebral tissue with its potentially "contaminating" amyloid plaques and neurofibrillary tangles (Glenner and Wong 1984b). They used the chaotropic salt guanidine hydrochloride (at 6M) to solubilize and then chromatographically enrich the amyloid subunit, which ran as a $4.2 \mathrm{kDa}$ band on SDS-PAGE. HPLC purification of the protein and amino-terminal sequencing to residue 24 revealed a unique sequence (their report of a glutamine rather than glutamate at position 11 was corrected in their subsequent sequencing of Down's syndrome meningovascular $A \beta)$. In this initial report, Glenner and Wong suggested that this novel peptide might turn out to be derived from a serum precursor and that it could "provide a diagnostic test for Alzheimer's disease and a means to understand its pathogenesis." Whereas the first of these three predictions turned out not to be true, the second and third clearly did.

Shortly after this paper appeared, Glenner and Wong published a highly similar study (Glenner and Wong 1984a) which showed that the meningovascular amyloid subunit in Down's syndrome brains was the same " $\beta$-protein," as they had dubbed it. Glenner called attention to this evidence of a key biochemical relationship between Down's syndrome and AD, a concept he had touted as early as 1979 in a prescient article in Medical Hypotheses (Glenner 1979). He stressed that Down's syndrome may be a "predictable model" for $\mathrm{AD}$ and further suggested that "the genetic defect in Alzheimer's disease is localized on chromosome 21." Glenner reasoned that, because trisomy 21 led to Alzheimer-type $A \beta$ accumulation in vessels and plaques, familial $\mathrm{AD}$ itself might well involve a defect in the precursor of the $\beta$-protein on this chromosome. This prediction turned out to be true in part; the first gene implicated in a familial form of $\mathrm{AD}$ was indeed the $\beta$-amyloid precursor protein. What Glenner apparently did not recognize - or at least state at the timewas the heterogeneity of familial forms of $\mathrm{AD}$ as well as the notion that many cases may not be genetically determined. Nevertheless, these two brief papers in Biochemical and Biophysical Research Communications, although not viewed as potentially seminal in the months after their publication, turned out to provide both the factual and conceptual underpinnings for all subsequent research on $\beta$-amyloidosis in $\mathrm{AD}$.

During the years 1983-1985, efforts independent of those of Glenner were made in several laboratories to isolate and sequence the amyloid in senile plaque cores (Fig. 1) from $\mathrm{AD}$ brains. These efforts began before the identification of the vascular $A \beta$ peptide by Glenner and Wong, but they were greatly facilitated by it. In 1983, Allsop, Landon, and Kidd reported a method for isolating intact neuritic plaque cores from postmortem $\mathrm{AD}$ brain and found them to be insoluble in various denaturants (Allsop et al. 1983). They published an amino acid composition which did not resemble any previously described amyloid protein. The authors described a variety of contaminants in their final preparations, including bacteria, leading to concerns about the accuracy of this composition, although subsequent methods produced core preparations of greater purity but generally similar composition, signifying the relative insensitivity of the amino acid composition of partially purified proteins as a biochemical comparator.

In the laboratories of Masters and Beyreuther, Roher, Selkoe, and Frangione, distinct but partially related methods for purifying 


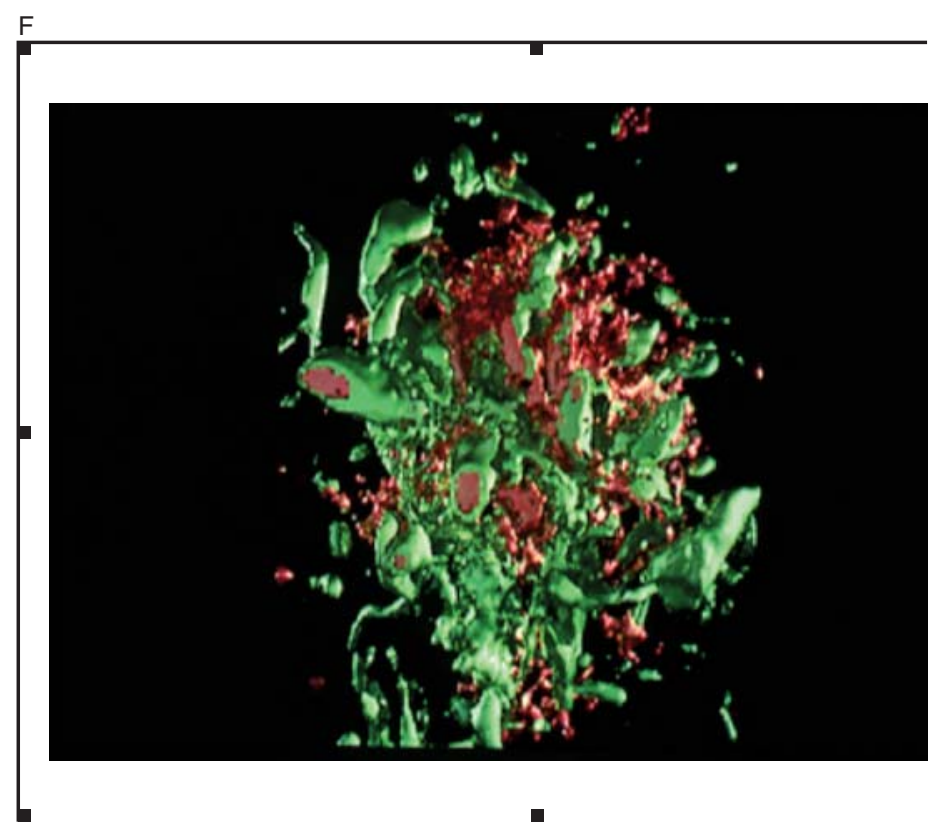

Figure 1. Three-dimensional reconstructed image by confocal microscopy of a neuritic (senile) plaque in the cortex of a patient dying with Alzheimer disease. Red labeling is by an antibody to amyloid $\beta$-protein which reveals the extracellular amyloid; green labeling is with an antibody against p-Tau which reveals intimately associated dystrophic neurites. Note that this plaque core is not a solid mass of amyloid but is fragmented and porous and contains abnormal cell processes intercalated within it. (Image courtesy of Dr. Eliezer Masliah, University of California, San Diego, CA.)

and solubilizing amyloid plaque cores from postmortem AD brain were developed. Masters and colleagues first reported the protein subunit of amyloid plaque cores, using a method which used nonionic detergent extraction of brain, pepsin digestion, and sucrose density gradient fractionation (Masters et al. 1985). The resultant cores were found to be approximately $90 \%$ pure by microscopy and were partially soluble in high concentrations (10\%) of SDS and BME and fully soluble in approximately $70 \%$ formic acid. By both HPLC and SDS/ urea PAGE, the formic acid-solubilized core protein ran not only at $\sim 4.3 \mathrm{kDa}$ but also at $\sim 8,12$, and $16 \mathrm{kDa}$, demonstrating the ready association of the monomer into SDS-stable oligomers. Masters and Beyreuther pointed out that the molecular mass, amino acid composition and amino-terminal sequence of the protein they isolated from cores were essentially identical to those described for vascular $A \beta$ by Glenner, although their analyses showed considerable amino-terminal "raggedness" in the plaque-derived protein. They concluded that the shared $4 \mathrm{kDa}$ subunit indicated a common origin for the plaque and vascular amyloids in AD. Again, A $\beta$ peptides isolated from $\mathrm{AD}$ and Down's syndrome plaques were indistinguishable. The amino-terminal heterogeneity reported by Masters and Beyreuther was striking, in that only $12 \%$ of the sequenced protein began at Asp1, with $64 \%$ starting at Phe4 and the remainder at downstream residues, perhaps deriving in part from their use of pepsin digestion during plaque purification. In Masters' report, Glenner's 24-residue sequence was extended to residue 28 , although the identities of two of those additional four residues were later revised.

Plaque core purifications and analyses performed at that time in three other laboratories provided largely consistent findings. 
The various methods employed took advantage of the insolubility of the amyloid cores in detergents such as SDS and their relative resistance to quantitative digestion by proteases. In the studies of Roher et al. (1986) and Gorevic et al. (1986), as in that of Masters et al. (1985), peptidases were used to diminish contaminants, but this approach raised the possibility of partial digestion of $A \beta$ itself and the creation of some of the observed amino-terminal heterogeneity. In the study of Selkoe et al. (1986) the use of extensive SDS extraction of the cores, then sucrose gradient centrifugation, and then a two-step fluorescence-activated particle sorting (FACS) led to SDS-insoluble plaque cores that were $>90-95 \%$ pure by electron microscopy, enabling an estimate (via amino acid analysis) of the protein content of a single plaque core: 60-130 pg. However, the attempts of Selkoe and colleagues to sequence this purified plaque amyloid after its solubilization in formic acid or saturated guanidine thiocyanate showed a blocked amino terminus. In subsequent years, biochemical and immunocytochemical studies from several laboratories made clear that the amino termini of plaque $A \beta$ peptides are heterogeneous and include derivatized and aminoterminally blocked species, e.g., pyroglutamate at residue 3. It is likely that the degree of aminoterminal heterogeneity and the precise termini obtained in various biochemical analyses of plaque cores depends in considerable part on the biochemical nature and harshness of the extraction protocol. It has been shown that particular purification reagents can chemically alter $A \beta$ structure, for example, the oxidation of Met35 in the presence of formic acid. Other types of amino acid modifications of plaque $\mathrm{A} \beta$, such as racemization and isomerization of its aspartates (e.g., D-aspartate and L- and D-isoaspartates) or formylation of serines during formic acid solubilization, have been reported. The former changes may occur during the prolonged aging of the deposited amyloid proteins in vivo, whereas the latter is an artifact of an in vitro method of solubilization.

One amino-terminal modification that has received particular attention is the proteolytic removal of residues 1 and 2 (Asp and Ala) and the subsequent cyclizing of residue 3 (Glu) to a pyroglutamate (designated $\mathrm{N}-3 \mathrm{pE}$ ). First described in biochemical extracts of $\mathrm{AD}$ cortex (Mori et al. 1992), this truncated species was found to be detectable immunohistochemically in many diffuse (i.e., mostly nonfibrillar) plaques in $\mathrm{AD}$ and $\mathrm{DS}$ cortex (Saido et al. 1995). This truncation increases the aggregation kinetics of $A \beta$ (D'Arrigo et al. 2009; Sanders et al. 2009; Wirths et al. 2010) and also obviates the amino-terminal binding of those therapeutic antibodies which target Asp1 of A $\beta$ (Gardberg et al. 2009). Recent work has shown that glutaminyl cyclase, an enzyme in brain and other tissues which cyclizes exposed glutamates, can do so with high efficiency at Glu3 (Seifert et al. 2009) after removal of the first two residues by aminopeptidases (Schlenzig et al. 2009; Sevalle et al. 2009). The amount of $A \beta p E 3$ in the brains of APP transgenic mice can increase with time, suggesting that the deposits begin with full-length $A \beta_{1-x}$, some of which is first truncated by local aminopeptidase activity and then modified by glutaminyl cyclase (Wirths et al. 2010). Other changes in the amino terminus, including pathogenic mutations at residues 6 and 7 (Ono et al. 2010), may have major effects on oligomerization.

Taken together, the early biochemical analyses of the amyloid fibrils in meningeal vessels and cerebral plaque cores established that the subunit in both cases was a highly hydrophobic $\sim 4 \mathrm{kDa}$ protein with a unique sequence that had a strong tendency to self-aggregate into stable dimers, trimers, and tetramers, higher oligomers and, ultimately, typical $8 \mathrm{~nm}$ amyloid fibrils. One interesting sidelight of these studies was the observation that the $A \beta$ derived from plaque cores was generally more insoluble than that from vascular deposits. For example, $6 \mathrm{~m}$ guanidine hydrochloride could effectively solubilize the latter but not the former, whereas the stronger chaotropic salt, guanidine thiocyanate, at saturated $(6.8 \mathrm{M})$ concentrations, could solubilize the cores (Selkoe et al. 1986). The use of concentrated formic acid by Masters and coworkers provided a reagent that appeared to bring even the most insoluble amyloid fibers in $\mathrm{AD}$ brains into 
Biochemistry of Amyloid $\beta$-Protein and Amyloid Deposits in AD

solution, and it has subsequently been widely used for this purpose. That it can do so indicates that, in general, cerebral $A \beta$ proteins which assemble into amyloid fibrils undergo little or no covalent cross-linking.

Although the identity of the protein subunit of Alzheimer amyloid was thus well established by 1986 , the carboxy-terminal sequence beyond residue 28 and the molecular origin of this small peptide remained unclear. As detailed in Haass et al. (2011), it was the power of molecular biological approaches that enabled the elucidation of its full length and how it actually arose from proteolysis of a large precursor polypeptide (Kang et al. 1987).

In the almost 30 years since the biochemical characterization of AD amyloid deposits commenced, we have come to realize that the complexity of this relatively short peptide is determined in part by the microenvironment in which it is generated and resides. Although small amounts can be produced in the endoplasmic reticulum and other vesicular organelles in the secretory pathway, much of the peptide appears to arise from APP that has trafficked to the cell surface and is then sequentially processed by $\beta$ - and $\gamma$-secretase (both are aspartyl proteases) in the mildly acidic environment of recycling endosomes (Selkoe 1994; Kaether et al. 2006; Cirrito et al. 2008; and see Haass et al. 2011). As mentioned above, the peptide isolated from fibrillar amyloid plaques shows substantial heterogeneity at both its amino and carboxyl termini. Its biochemical properties vary significantly depending on its terminal residues, particularly at the hydrophobic carboxyl terminus. Although the field has focused until recently on two peptide lengths, the most abundantly produced species $(\mathrm{A} \beta 1-40)$ and the far less abundant but more aggregation prone $A \beta 1-42$, this is a simplification, as the variability of carboxy-terminal lengths created by $\gamma$-secretase extends at least from $A \beta_{36}$ to $A \beta_{43}$ (Kang et al. 1987). This heterogeneity arises secondary to the initial $\varepsilon$-cleavage of APP by the presenilin $/ \boldsymbol{\gamma}$-secretase complex at the membrane/cytoplasmic interface, namely at Leu49-Val50 (Weidemann et al. 2002), followed by processive intramembrane processing by this protease in an amino-terminal direction (i.e., first $\varepsilon$, then $\zeta$ and then $\gamma$ cleavages) (QiTakahara et al. 2005; Takami et al. 2009; and see Haass et al. 2011).

\section{AMYLOID FIBRILS OFA $\beta$ : STUDIES OF THEIR STRUCTURE AND PROPERTIES}

The pathognomonic lesions of $\mathrm{AD}$ are the fibrillar extracellular deposits of $A \beta$ in parenchymal plaques and vascular amyloid and the intraneuronal neurofibrillary tangles, which also have the tinctorial properties of amyloid (Serrano-Pozo et al. 2011). How A $\beta$, including its buffer-soluble oligomeric forms, may induce the formation of intracellular tangles of the tau protein is discussed elsewhere (Mandelkow and Mandelkow 2011; Mucke and Selkoe 2011). Here we will review the pathway which converts the $A \beta$ region from its largely $\alpha$-helical conformation when APP is embedded in the lipid membrane to its gradual aggregation into large polymers (filaments) rich in cross- $\beta$ sheet structure in the extracellular space of the brain. The conversion of $\alpha$-helix or random coil stretches within normally soluble proteins into principally $\beta$-sheet rich assemblies is a common theme in several neurodegenerative diseases. Drawing on the analogous prion theory, it is also possible for a $\beta$-sheet conformer to induce or "seed" an $\alpha$-helical conformer (or some other metastable intermediate) to adopt $\beta$ sheet structure (Eisele et al. 2009, 2010). What structural relationship such intermediates in fibrilogenesis have to the soluble, diffusible oligomers of $\mathrm{A} \beta$ detected in $\mathrm{AD}$ brain remains uncertain. Despite more than 50 years of structural analysis, the atomic resolution of classical amyloid fibrils remains incomplete. Although many techniques have been applied (including solid-state nuclear magnetic resonance and cryo-electron microscopy), the basic noncrystalline subunit in the $A \beta$ fibril has prevented progress (Caspar 2009; Kajava et al. 2010). Moreover, most of the data available on the structure of $A \beta$ and its fibrils come from studies of synthetic $A \beta$ peptides, and it remains unclear whether these accurately model the natural $A \beta$ assemblies found in $\mathrm{AD}$ brain. 
Theoretical Computational and Molecular Dynamic Models of the A $\beta$ Amyloid Fibril

Although the monomeric subunit of fibrils is thought to consist of two $\beta$-strands connected by a turn, the ambiguous nature of the amino and carboxyl termini have precluded development of a detailed model (Olofsson et al. 2009b; Paparcone and Buehler 2009; Ramos et al. 2009). The convoluted carboxy-terminal folding seen in a constrained oligomeric structure (Streltsov et al. 2011) provides a caveat that the simple, $U$-shape $\beta$-turn may be an oversimplification. Some variability in this turn region has now been identified using molecular dynamic (MD) simulations of dimers compared to trimers/pentamers (Horn and Sticht 2010) and a triangular subunit forming a threefold hexamer (Zheng et al. 2010). Constraining the $\beta$-turn by linking Asp 23 to Lys 28 also results in a system with increased fibrillogenic propensity (Reddy et al. 2009a). Placing the $\beta$-turn on a constraining physical interface also affects assembly (Fu et al. 2009), and this could have implications for $A \beta$ assembly when some of the peptide is bound to cell membranes, as is likely in the brain. Assembly at low or neutral $\mathrm{pH}$ may have an effect on the registration of the subunits within the fibril (Negureanu and Baumketner 2009). Interpeptide hydrogen bonds may play a major role in fibril growth, based on MD modeling (Reddy et al. 2009b; Takeda and Klimov 2009b, 2010). Oxidation of Met35 and assembly in quiescent versus agitated conditions have also been modeled and found to have effects on the hydrophobic surfaces exposed on the fibrils (Wu et al. 2010a).

\section{Structural Studies of Synthetic A $\beta$ Fibrils}

Low-resolution ( $8 \AA$ ) cryo-electron microscopy of synthetic $A \beta_{40}$ and $A \beta_{42}$ reveals similar protofilament structures, with approximately 2.5 peptides per cross- $\beta$ repeat per protofilament (Schmidt et al. 2009). The lack of an integral number per repeat suggests that the assembly may have undefinable amino termini within a tetrameric structure (Caspar 2009). Other low-resolution (10 ̊) cryo-EM reconstructions have suggested that the carboxyl terminus forms the inside wall of a hollow core (Zhang et al. 2009d). Two-dimensional infrared spectroscopy discloses intramolecular water molecules around residues $17 / 34$ and $18 / 36$ in a conformation with a presumptive $\beta$-turn at $23 / 28$. Substitutions around Glu22 and Asp23, either artificial or mimicking the pathogenic "Arctic" or "Iowa" FAD mutations, produce major effects on rates of aggregation (PerálvarezMarín et al. 2009; Tycko et al. 2009), perhaps through a mechanism that involves off-registry side chain interactions (Takeda and Klimov 2009c).

\section{DIFFUSIBLE OLIGOMERS OF A $\beta$}

If one considers the trajectory of biochemical studies of $A \beta$, it is clear that the field has moved over the last dozen years from an initial emphasis on the fibrillar state found in amyloid plaques and meningocerebral vessels to a range of smaller, oligomeric $A \beta$ assemblies that are relatively soluble and diffusible and thus more able to exert a toxic effect on the neuronal plasma membrane, including synapses. A rich and confusing vocabulary has developed to describe the oligomers of $A \beta$ as they assemble along pathways which may or may not lead to the classical $8 \mathrm{~nm}$ amyloid fibrils found in plaques and blood vessels (Table 1). The methods of analysis often determine nomenclature: biochemical characterization of synthetic or natural (cellular and brain) A $\beta$ peptides using SDS-PAGE or size exclusion chromatography has led to descriptions of assemblies containing a few (e.g., 2-20) monomers, usually designated soluble oligomers; other methods, particularly those using morphological or biophysical approaches on synthetic $A \beta$ such as electron microscopy or atomic force microscopy, may describe linear protofilaments (often $\sim 4 \mathrm{~nm}$ in diameter) or spherical/globular particles, each of which has been interpreted as a precursor of amyloid fibrils. It is important to emphasize here that many of the synthetic $A \beta$ assembly forms reported in the literature have been made in vitro using supraphysiological concentrations of a single-length peptide (e.g., A $\beta 1-40)$, and 
Biochemistry of Amyloid $\beta$-Protein and Amyloid Deposits in AD

Table 1. A $\beta$ assemblies described in the literature

A rich vocabulary that depends on the source of the peptide, the method of analysis, and the laboratory involved

$\mathrm{A} \beta$ oligomers of natural or synthetic origin, as visualized chromatographically and/or on denaturing protein gels: monomers $\left(A_{4}\right)$, dimers $\left(A_{8}\right)$, trimers, tetramers $\left(A_{16}\right)$, pentamers, hexamers, dodecamer/12-mer $\left(A \beta^{*} 56\right)$, lower/higher order oligomers $\left[(A \beta)_{n}\right]$

Other synthetic oligomeric $A \beta$ assemblies: amyloid- $\beta$-derived diffusible ligands (ADDLs); $A \beta$ micelles, annular ( pore-like) structures, ( pre-)globulomers (globular oligomers), growth-arrested colloid particles, metastable aggregates, nanopore-like structures, neuroparticles, paranuclei/nucleating seeds, on/off pathway intermediate states, spherical aggregates, etc.

Synthetic A $\beta$ fibrillar assemblies: protofibrils, prefibrils, fibrillar oligomers, nanofibrils

the occurrence of closely similar or identical species in $\mathrm{AD}$ brain tissue may not have been explicitly confirmed structurally (immunochemical cross-reaction would not be sufficient confirmation). One caveat in this regard is that natural $\mathrm{A} \beta$ oligomers isolated from $\mathrm{AD}$ brain tissue or APP-expressing cell cultures are far more potent in electrophysiological or cytotoxicity assays than are synthetic assembly mixtures such as ADDLs ("A $\beta$-derived diffusible ligands") (Lambert et al. 1998) or protofibrils (Harper et al. 1997; Walsh et al. 1997), which require high nanomolar concentrations to induce biological effects, suggesting that they contain many "off-pathway" (unnatural) assembly forms that do not interact with neuronal membranes the way natural oligomers do. Indeed, some such synthetic "oligomers" have not been proven to be truly soluble in aqueous buffers (i.e., not pelletable at 100,000 $\mathrm{g}$ in an ultracentrifuge), which is the case for natural oligomers (see, for further reviews of the complexity of $A \beta$ assembly forms, Haass and Selkoe 2007; Walsh and Selkoe 2007; Di Carlo 2010; Sakono and Zako 2010).

\section{Synthetic $A \beta$ as a Substrate for Oligomer Formation}

Ever since the sequence of $A \beta$ became known, the easiest approach to study assembly has been to aggregate synthetic peptides at supraphysiological concentrations in vitro (Castano et al. 1986; Gorevic et al. 1986; Kirschner et al. 1987). Classical biochemical analyses of the synthetic aggregates have been supplemented with newer biophysical methods such as scanning tunneling microscopy (Liu et al. 2009a; Ma et al. 2009), atomic force microscopy (Wu et al. 2010b), quartz crystal microbalance (Ogi et al. 2009), hydrogen exchange mass spectrometry (Zhang et al. 2009a), electron capture dissociation Fourier-transform ion cyclotron resonance mass spectroscopy (Sargaeva et al. 2009), single-molecule spectroscopy (Ding et al. 2009), fluorescence photobleaching and quenching (Reinke et al. 2009; Edwin et al. 2010), click peptide technique (Taniguchi et al. 2009), and ion mobility coupled with mass spectrometry (Bernstein et al. 2009). The experimental conditions for assembling synthetic $A \beta$ monomers into oligomers vary enormously with regard to the roles of temperature, salts, detergents, lipids, metal ions, fatty acids, and other molecules (Sahoo et al. 2009; Yu et al. 2009; Ahmed et al. 2010; Ladiwala et al. 2010; Ryan et al. 2010), and each such condition provides constraints on the techniques the can be used to study the synthetic peptide. Stabilization of synthetic dimers by cross-linking oxidized tyrosine-10 residues (Ono et al. 2009) or introduced cysteine residues (O'Nuallain et al. 2010) also provides a way to study this smallest oligomer and its role in the dynamic equilibrium of $A \beta$ assembly.

Amino acid substitutions and modifications can readily be introduced into synthetic peptides. However, to what degree these synthetic changes adequately model the in vivo situation is often disregarded by investigators. For example, the familial intra- $\mathrm{A} \beta$ mutations that occur in dominant fashion at position 22 or 
23 (E22G, E22Q, E22K, and D23N) result in the accrual in vivo of a mixture of mutant and wildtype peptides of heterogeneous lengths, but this is often not modeled in vitro (Masuda et al. 2009; Murray et al. 2009b; Brorsson et al. 2010). Nevertheless, synthetic $A \beta$ studies of this critical region do provide some information on the effects of these mutations on the $\beta$-turn at $25 / 26$ versus $22 / 23$ and consequent effects on oligomerization and toxicity in vitro.

\section{Molecular Dynamic Approaches to Understanding Synthetic A $\beta$ Oligomers}

Although some progress in obtaining atomic resolution of the amino terminus and carboxyl terminus of synthetic $A \beta$ has been made, the overall structure(s) of the oligomer(s) at different assembly points remains elusive. A plethora of MD simulations and theoretical modeling has emerged. Starting at the amino terminus, Takeda and Klimov (2009a) find that aminoterminal truncation has an effect on oligomer (dimer) formation. The metal-binding region of $A \beta$ around residues $6-14$ has not yet been adequately addressed by MD studies (see below), and there are conflicting results on models obtained for the loop and $\beta$-strands associated with the residue $16-35$ region (Chebaro et al. 2009; Miller et al. 2009; Murray et al. 2009a; Hamley et al. 2010; Wei et al. 2010). The oxidation state of Met35 has long been of interest (Haeffner et al. 2010); this residue in the hydrophobic carboxyl terminus may play a role in oligomerization driven by hydrophobic interactions (Zhao et al. 2009). Although it has long been suspected that the highly hydrophobic carboxyl terminus of $\mathrm{A} \beta 42$ is a principal determinant of aggregation, its biophysical role in oligomerization has only recently begun to be addressed using synthetic peptides (Murray et al. 2009a; Li et al. 2010). The structure of the carboxyl terminus may involve novel metastable conformations ( $\beta$-hairpin at $35-37$ ), but these remain to be confirmed by crystallographic methods (Wu et al. 2009). Higher order oligomers (pentameric/hexameric assemblies) have been studied by MD and show different effects between the central hydrophobic and carboxy-terminal regions when $A \beta_{40}$ and $A \beta_{42}$ are compared (Urbanc et al. 2010). Synthetic oligomers are also being used in attempts to discover small molecules which are able to target these specific assemblies (Davis and Berkowitz 2009a; Davis et al. 2009; Feng et al. 2009; Liu et al. 2009a; Nerelius et al. 2009; Pitt et al. 2009; Riviere et al. 2009; Smith et al. 2009; Sun et al. 2009; Yamin et al. 2009; Hawkes et al. 2010; Ladiwala et al. 2010).

\section{Recombinant A $\beta$ Oligomers}

$A \beta$ oligomers obtained using recombinant techniques appear to be as challenging to work with as their synthetic counterparts (Picone et al. 2009; Walsh et al. 2009; Streltsov et al. 2011). Nevertheless, recombinant constructs have provided a way to conformationally constrain oligomerized $A \beta$ assemblies and are beginning to provide novel insights into lowerorder oligomers (e.g., dimers and tetramers) at atomic resolution (see Fig. 2; Streltsov et al. 2011). Recombinant $A \beta_{42}$, with its strong fibrillogenic propensity, is coming under study (Zhang et al.2009c; Finder et al. 2010). As a bacterially derived product, it is difficult to fully exclude impurities and adventitious factors that might interact with and co-purify with the recombinant peptide. Although purified synthetic $A \beta$ peptides can also contain impurities (e.g., racemized or truncated peptides), the faster aggregating and more potent toxic properties of the recombinant material raise the question of the presence of pro-aggregating seeds and are worthy of further investigation (Finder et al. 2010).

\section{Tissue- and Cell-Derived Natural Oligomers}

The ultimate goal of studying the biochemistry of $A \beta$ is to understand its nature and biological properties as it accumulates in the human brain. Early studies detected SDS-stable low-n oligomers on western blots of AD brain extracts (e.g., Masters et al. 1985; Roher et al. 1993), although their biological activities were not studied at that juncture. The major advance of generating mouse lines transgenic for human 


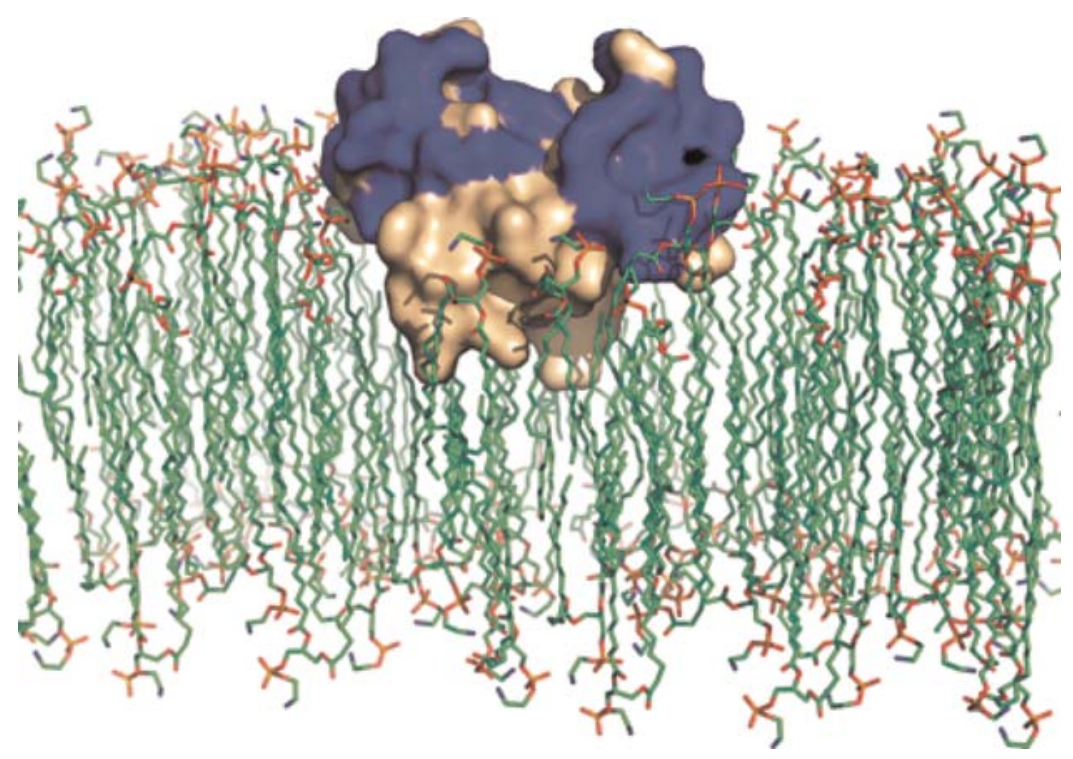

Figure 2. Model of potential interactions of $A \beta_{18-41}$ dimer with membrane lipid bilayers. The hydrophobic dimer-dimer interface of the $A \beta_{18-41}$ tetramer is intercalated into the membrane surface through nonelectrostatic interactions, whereas hydrophilic aspects (blue) with metal-binding sites (black) are on the membrane surface. (From Streltsov et al. 2011; reprinted, with permission, from the author.)

APP (Games et al. 1995; Hsiao et al. 1996) has provided dynamic information about which species accrue most quickly (principally $A \beta$ ending at residue 42) and how they aggregate and deposit over time (e.g., Hamaguchi et al. 2009; Philipson et al. 2009; Tomiyama et al. 2010; and see LaFerla and Duff 2011). The in situ association of $A \beta$ oligomers with lipid membranes (Liu et al. 2010b), including postsynaptic densities (Koffie et al. 2009), in APP transgenic mouse brains helps us understand how these potentially toxic $A \beta$ species are compartmentalized. However, only a small number of studies characterizing soluble oligomers per se in transgenic mouse brains has been published (Kawarabayashi et al. 2001; Lesne et al. 2006; Shankar et al. 2009; Pham et al. 2010).

Turning now to studies of human brain tissue, soluble (aqueously extractable and nonpelletable) forms of $\mathrm{A} \beta$ in postmortem $\mathrm{AD}$ cortex, which include monomers and various oligomers, have become recognized as stronger quantitative correlates of degree of cognitive impairment shortly before death than are amyloid plaques (see Fig. 3; McLean et al. 1999; Tomic et al. 2009; Woltjer et al. 2009; McDonald et al. 2010). Soluble $A \beta$ oligomers extracted from the cortex of typical $\mathrm{AD}$ subjects have been shown to potently inhibit long-term potentiation (LTP), enhance long-term depression (LTD), and reduce dendritic spine density in slices of normal rodent hippocampus (Shankar et al. 2008). The extracts of soluble oligomers also disrupted the memory of a learned behavior after intracerebroventricular injection in normal rats. These effects could be principally attributed to dimers, the major SDS-stable oligomer detected on western blots of $\mathrm{AD}$ cortex. Importantly, insoluble amyloid plaque cores from the same brains did not impair LTP unless they were first solubilized to release $\mathrm{A} \beta$ dimers and other oligomers, suggesting that plaque cores per se have low bioactivity but sequester $A \beta$ dimers that can be synaptotoxic if released (Shankar et al. 2008). There is also evidence that soluble $A \beta$ oligomers isolated from $\mathrm{AD}$ cortex can induce hyperphosphorylation of tau protein at AD-relevant epitopes, followed by progressive collapse of the 

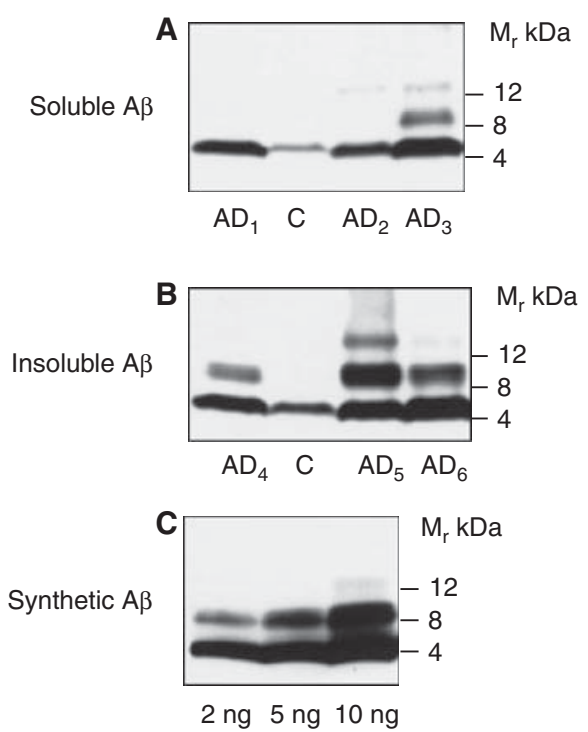

Figure 3. Representative western blots showing $A \beta$ in frontal cortex of selected Alzheimer disease (AD) and control subjects. (A) Soluble $A \beta$ in $175,000 \mathrm{~g}$ supernatants after a single extraction in phosphatebuffered saline. (B) Insoluble $\mathrm{A} \beta$ extracted from the $175,000 \mathrm{~g}$ pellets. $(C)$ To enable quantification and between-gel comparisons, synthetic $A \beta_{40}$ standard curves were run on each gel. The markers designate monomeric $(4 \mathrm{kDa})$, dimeric $(8 \mathrm{kDa})$, and trimeric $(12 \mathrm{kDa})$ forms of $\mathrm{A} \beta$. (From McLean et al. 1999; reprinted, with permission, from the author.)

microtubule cytoskeleton and neuritic dystrophy (Jin et al. 2011).

Although these results suggest a synaptotoxic role for dimers, there are other soluble oligomers detectable in $\mathrm{AD}$ brain, including a $\sim 56 \mathrm{kDa}$ putative dodecamer (Lesne et al. 2009). A similar species has been detected in the brains of some APP transgenic mice and its level is shown to correlate with the occurrence of behavioral deficits; isolation of this species from mouse brain and subsequent icv injection into wild-type rats induced decreased spatial memory performance (Lesne et al. 2006; LaFerla and Duff 2011). In vivo, it is likely that there exists an array of low- and medium-sized oligomers, at least some of which appear to be in equilibrium with fibrils in plaques. The latter notion is supported by the occurrence of a halo of dystrophic neurites immediately around fibrillar plaques, with the neuritic dystrophy diminishing as one moves farther from the plaque; this halo zone is also immunoreactive with certain antibodies that selectively detect small oligomers of $A \beta$ (Meyer-Luehmann et al. 2008; Koffie et al. 2009).

Using immunoaffinity techniques, Noguchi et al. (2009) have isolated $10-15 \mathrm{~nm}$ spherical $\mathrm{A} \beta$ assemblies (mass $>100 \mathrm{kDa}$ ) from $\mathrm{AD}$ cortex. How these relate to the lower order SDS-stable oligomers discussed above remains to be determined. Other post-translationally modified $A \beta$ species, such as partial aspartate isomerization (Tomidokoro et al. 2010) and carboxy-terminal heterogeneity that includes longer $A \beta_{43}$ peptides (Welander et al. 2009), are being uncovered by isolating $A \beta$ directly from postmortem human brain. In addition, direct analysis of human brain $A \beta$ fibrils may disclose structural differences not predictable from similar analyses of synthetic fibrils (Paravastu et al. 2009).

Neuronally generated $A \beta$ monomers and perhaps various oligomers are presumed to equilibrate within the interstitial fluid of the brain and to turn over in relation to the rates of $A \beta$ production, clearance, and aggregation into amyloid fibrils. From the interstitial compartment or brain parenchyma, soluble $A \beta$ monomers and oligomers may enter into the CSF compartment (Englund et al. 2009; Fukumoto et al. 2010) and even the peripheral blood circulation (Roher et al. 2009; Xia et al. 2009). Although much more work is required to establish the existence of blood-borne $\mathrm{A} \beta$ oligomers and confirm their cerebral origin, there is preliminary evidence that blood dimer levels may correlate with clinical features of $\mathrm{AD}$ (Villemagne et al. 2010; see also Blennow et al. 2011). Interestingly, such blood-borne dimers are associated with blood cellular membranes (mainly white cells and platelets) and may increase as the natural history of $\mathrm{AD}$ advances (Villemagne et al. 2010). In contrast, levels of $A \beta 42$ monomers in both the CSF and plasma are generally considered to fall as $\mathrm{AD}$ progresses (Lui et al. 2010a; Blennow et al. 2011). 
Biochemistry of Amyloid $\beta$-Protein and Amyloid Deposits in AD

\section{THE INTERACTIONS OF A $\beta$ WITH OTHER MOLECULES: SERENDIPITOUS BYSTANDERS AND/OR INTIMATE PARTNERS IN PATHOGENESIS?}

Early compositional analyses performed on isolated amyloid plaque cores suggested that $A \beta$, although clearly the major component, was not the sole protein constituent. Moreover, nonproteinaceous components were also identified to varying degrees in enriched-albeit not fully purified-plaque core preparations. It has been difficult to determine on a biochemical basis alone which of these additional constituents are important and integral components of the amyloid plaques and which might become adventitiously associated with $\mathrm{A} \beta$ during plaque purification from homogenized brain tissue. When a non-A $\beta$ component of plaques is identified and antibodies are raised to it, these can be used to attempt to label amyloid plaques in situ at both the light and electron microscopic levels. Positive results suggest that a particular protein is indeed associated with the amyloid deposits, although not an integral component of the amyloid fibrils because, like other tissue amyloids, the fibrils should be composed solely of the specific subunit protein. Indeed, the ability to reconstitute amyloid fibrils with an ultrastructure closely resembling the fibrils seen in situ from synthetic $A \beta$ peptides alone has strongly suggested that the sole component of the amyloid filaments in vivo is $A \beta$. A careful proteomic analysis of amyloid plaque cores isolated from postmortem $\mathrm{AD}$ cortex by laser capture microdissection concluded that the only protein constituent detectable by mass spectrometry in the isolated cores was A $\beta$ (Soderberg et al. 2006), supporting the conclusion that the plaque amyloid fibrils are composed of just this protein type. It should be noted, however, that the fibrils may consist in part of heteropolymers of slightly different $A \beta$ peptides, rather than just homopolymers of a single peptide length (e.g., A $\beta 1-42)$.

Nevertheless, a variety of other molecules has been found to be loosely or more tightly associated with amyloid deposits during their isolation and can sometimes be shown immunocytochemically in diffuse and/or compacted plaques in situ. Because the morphology of senile plaques indicates the presence of several distinct cellular elements that are intimately apposed, including dystrophic axons and dendrites (Fig. 1) and the processes of activated microglia and reactive astrocytes, any of these as well as local microvessels could potentially be sources of various non-A $\beta$ constituents of the plaques. In short, mature amyloid (neuritic) plaques are heterogeneous mixtures of proteinaceous and nonproteinaceous constituents, and the temporal sequence of accrual of these elements onto the presumed initial $A \beta$ polymer has been difficult to determine.

A recently completed interactome of APP disclosed more than 200 different entities which interact with different domains of APP (128 validated, 74 putative), including a significant proportion interacting with the $A \beta$ region (Perreau et al. 2010). One of the earliest to be identified was the enzyme acetylcholinesterase (AChE; Friede 1965), perhaps paradoxical because of its subsequent role as a therapeutic target for $\mathrm{AD}$ and surprising in that the mechanistic basis for the co-location of AChE with the amyloid plaques remains uncertain (De Ferrari et al. 2001). Most of the identified molecular interactors of $A \beta$ in the brain remain equally mysterious and often raise the question of bystander versus functionally significant partner.

\section{Metal Ions}

Because of their ubiquitous presence in human tissues, the bioavailable metal ions, $\mathrm{Cu}, \mathrm{Zn}$, and $\mathrm{Fe}$, have been obvious choices for investigation of amyloid association. For decades, uncertainty has reigned over the quantitative elemental analysis of whole brain homogenates-and of isolated plaques or tangles - in AD compared to normal aged controls and other neurodegenerative diseases. At the level of grey matter homogenates, there is no agreement that any particular metal ion is specifically elevated or lowered in $\mathrm{AD}$ brain. Most techniques have detected elevations in $\mathrm{Cu}, \mathrm{Zn}$, or $\mathrm{Fe}$ in $\mathrm{AD}$ amyloid plaques, either in situ or after their 
purification (see, for example, Rajendran et al. 2009), but such analytical approaches have never been entirely convincing. The observations that both APP and A $\beta$ have sequences consistent with metal-binding motifs and metallo-complexing activities add a new dimension to this line of enquiry (Faller 2009; Duce et al. 2010). Measuring the affinities of metal-protein interactions is challenging (Xiao and Wedd 2010) but, as technologies have improved, the general rule has emerged that the metal affinities increase as the proteins move toward their sites of final subcellular compartmentalization and utilization. Thus, certain other proteins act as chaperones to take the metal ions into compartments where their higher affinity end-user proteins reside. The synapse has proven to be a subcellular site where ions such as $\mathrm{Zn}^{2+}$ and $\mathrm{Cu}^{2+}$ are used to modulate the activities of key excitatory NMDA/AMPA receptors. It is in the vicinity of this cellular compartment that $A \beta$ may interact with these divalent cations in a fashion that can alter the peptide's conformation. This metal-based mechanism, as well as the overall level of local excitatory neurotransmission (Cirrito et al. 2005), could help provide an explanation for the topographic selectivity of $A \beta$ aggregation and extracellular deposition in the $\mathrm{AD}$ brain, as there is an intriguing overlap between those areas of the brain rich in glutamatergic terminals, free vesicular zinc, and $A \beta$ amyloid plaques in certain APP transgenic mice (Stoltenberg et al. 2007).

With an emerging understanding of the pathways leading to soluble oligomer or insoluble fibril production, therapeutic strategies loosely termed as "anti-A $\beta$ aggregation" need to be refocused on the specific steps being targeted (Rodriguez-Rodriguez et al. 2009; Yadav and Sonker 2009; Dickens and Franz 2010), particularly with regard to the concept of "therapeutic chelation" of metal ions. The concept of therapeutic chelation needs to be qualified by the relative affinities each metal ion has for its target protein. Thus, metal "chaperone" is a preferred concept when discussing the reversible interactions divalent cations can have with $A \beta$, regardless of which oligomeric or fibrillar assembly is being considered.

\section{$A \beta$ and Copper}

The average $K_{D}$ of $\mathrm{Cu}^{2+}$ for $A \beta$ is about $10^{-10} \mathrm{M}$ (i.e., low nanomolar) for both soluble and fibrillar forms of the synthetic peptide in vitro (Rózga et al. 2010; Xiao and Wedd 2010). This means that other metallo-chaperone proteins with higher (i.e., high picomolar or greater) affinities will prevent $\mathrm{Cu}^{2+}$ binding to $\mathrm{A} \beta$. This criterion would include human serum albumin (Perrone et al. 2009), suggesting that $A \beta$ in locations (e.g., CSF or blood) remote from parenchymal brain compartments such as neurites and synapses should be unmetallated. Furthermore, therapeutic compounds designed to act as metal-ion chaperones with low picomolar affinities would be expected to compete with $\mathrm{A} \beta$ for $\mathrm{Cu}^{2+}$ binding only within the brain parenchyma.

$\mathrm{A} \beta$ may have more than one $\mathrm{Cu}^{2+}$-binding site (Behbehani and Mirzaie 2009; Jun et al. 2009; Sarell et al. 2009). Depending on the stoichiometry, $\mathrm{Cu}^{2+}-\mathrm{A} \beta$ interactions can cause synthetic $A \beta$ to aggregate in vitro principally via an oligomer-forming pathway or a fibrillogenic pathway (Brzyska et al. 2009; Moore et al. 2009; Olofsson et al. 2009a; Tõugu et al. 2009; Haeffner et al. 2010). That is, at subequimolar $\mathrm{Cu}^{2+}: \mathrm{A} \beta$ ratios, amyloid fibrils form; at supra-equimolar ratios, stable oligomers form first, then dityrosine cross-linkages occur (Smith et al. 2007). The principal $\mathrm{Cu}^{2+}$ binding site is coordinated within the first 16 residues and involves His6, His13, and His14, together with the first two residues (Asp1, Ala2) (Dorlet et al. 2009; Drew et al. 2009a,b; Hureau et al. 2009a,b). This coordination environment is pleiotropic (Drew et al. 2009b), adding to the complexity of the analysis (Drochioiu et al. 2009; Hureau et al. 2009a). As was predicted when the $A \beta$ sequence became known, the protonation of the histidine residues, dependent on $\mathrm{pH}$, should have a major effect in the $A \beta$ folding pathway: metallation and folding of $A \beta$ in the endosome/lysosome pathway will probably be quite different from that in the extracellular or peri-synaptic compartments.

$\mathrm{Cu}^{2+}$ as a redox-active entity can also induce oxidative modification to $A \beta$, particularly 
Biochemistry of Amyloid $\beta$-Protein and Amyloid Deposits in AD

at Tyr10 with consequent dityrosine covalent cross-links (Drew et al. 2009a,b; Moore et al. 2009; Jiang et al. 2010). Other residues, such as Met35, may participate (Barman et al. 2009; Butterfield et al. 2010), but this is not proven (da Silva et al. 2009). Whether the metalmodified $A \beta$ is capable of pro- or anti-oxidant activity is also uncertain (Baruch-Suchodolsky and Fischer 2009), but it is an important question that needs to be resolved in terms of understanding the toxicity of $A \beta$ oligomers. Reducing intracellular $\mathrm{Cu}^{2+}$ bioavailability has an inhibitory effect on $\mathrm{A} \beta$ oligomer formation (Crouch et al. 2009a).

\section{$\mathrm{A} \beta$ and Zinc}

In contrast to $\mathrm{Cu}^{2+}, \mathrm{Zn}^{2+}$ is redox inactive and therefore cannot be directly involved in any oxidative processes involving $A \beta$. In common with $\mathrm{Cu}^{2+}, \mathrm{Zn}^{2+}$ has pleotropic binding sites on $\mathrm{A} \beta$ (Damante et al. 2009; Talmard et al. 2009; Miller et al. 2010) which can serve to drive synthetic $\mathrm{A} \beta$ aggregation in vitro. The $\mathrm{Zn}^{2+}$-induced formation of cytotoxic $A \beta$ oligomers in proximity to excitatory glutamatergic synapses is believed to be a mechanism contributing to synaptic degeneration in AD (Deshpande et al. 2009). $\mathrm{Zn}-\mathrm{A} \beta$ complexes also become more resistant to proteolytic degradation in in vitro experiments (Crouch et al. 2009b), potentially allowing metal-bound $A \beta$ fibrils to accumulate in the extracellular space.

\section{$\mathrm{A} \beta$ and Iron}

Studies of $\mathrm{Fe}^{3+} / \mathrm{Fe}^{2+}$ complexes with $\mathrm{A} \beta$ indicate a potential pro-aggregating role for this abundant metal (Jiang et al. 2009a; Uranga et al. 2010), especially if evidence that $A \beta$ has significantly higher affinity for $\mathrm{Fe}^{2+}$ than does transferrin (Jiang et al. 2009a) is confirmed.

\section{A $\beta$ INTERACTIONS WITH CELL MEMBRANES, LIPOPROTEINS, AND MEMBRANE-ASSOCIATED PROTEINS}

The proteolytic release of A $\beta$ from APP is believed to occur principally in an endosomal/lysosomal compartment or from the surface of the plasma membrane (see Haass et al. 2011). Given the amphiphilic nature of $\mathrm{A} \beta$, it is not surprising that many potential interactions can occur once it is a free peptide. These interactions can be driven by phase/ interface effects, electrostatic (charge) interactions dependent on the $\mathrm{pH}$ of the microenvironment, and hydrophobic interactions if the hydrophobic carboxy-terminal region is able to re-associate with the lipid bilayer. These types of bonding apply also to $A \beta$ interactions with the lipoprotein particles formed with ApoE, ApoA, and ApoJ, as well as with other membrane-associated macromolecular complexes in the vicinity of synapses such as NMDA, AMPA, insulin, and nicotinic ACh receptors. All of these complex protein interactions are dependent in part on the conformation and state of assembly of $A \beta$ itself. When sequential fractions of postmortem $\mathrm{AD}$ brain homogenates are analyzed, the major pool of $A \beta$ lies in the detergent-insoluble (e.g., formic acidor guanidine-extractable) fraction, presumably representing rather insoluble amyloid plaques, but a considerable amount is apparently loosely associated with cellular membranes (e.g., the sodium carbonate-extractable fraction). The diffusible, aqueously extractable fraction (e.g., buffered saline extract) is generally less than $1-2 \%$ of the total recoverable brain $A \beta$. It is the membrane-associated pool of brain $A \beta$ which can be recovered in sodium carbonate or Triton that we will focus on now (see Relini et al. 2009 for a recent review).

\section{Phase/Interface Effects}

Most in vitro studies of the $\alpha$-helix to $\beta$-sheet conversion and aggregation of $A \beta$ peptides are conducted at concentrations 3-4 orders of magnitude greater than those found in vivo. Moreover, the special microenvironment in which $A \beta$ aggregation is believed to occur in vivo is not always taken into account, e.g., the relatively high concentrations of metal ions in and around synapses. The interface between the interstitial fluid phase and the surface of the plasma membrane is likely to be a critical factor in influencing the aggregation pathway 
of $A \beta$. A number of in vitro studies find this, showing interface clustering of $A \beta$ (Chi et al. 2010) that slows the lag phase of fibril formation (Hellstrand et al. 2010) by providing an environment for a hydrophobic layer adjacent to the membrane interface (Jiang et al. 2009b). Physical movement/agitation at the watermembrane interface may also promote fibrillogenesis (Morinaga et al. 2010; Wu et al. 2010a). The nature of this interface may therefore strongly affect the $A \beta$ folding pathway (Kayed et al. 2009). In contrast to the hydrophilic ectodomains of various proteins proposed to function as $A \beta$ receptors, membrane lipid surfaces seem a more biophysically plausible receptor for the highly hydrophobic $A \beta$ oligomers.

\section{Electrostatic/Charge Effects}

The role of negatively charged phospholipid head groups, sphingolipids, sialic acid, etc. in affecting the binding and oligomerization of $\mathrm{A} \beta$ is being increasingly examined (Kayed et al. 2009; Salay et al. 2009; Kotarek and Moss 2010; Sureshbabu et al. 2010). Smaller (1$2 \mathrm{~nm}$ diameter) synthetic $\mathrm{A} \beta$ oligomers have a greater tendency to bind such charged species than do those of larger $(4-5 \mathrm{~nm})$ size (Cizas et al. 2010). Local membrane charge may also alter the $\beta$-turn of synthetic $A \beta$ peptides (Grimaldi et al. 2010). Exposed phosphatidylserine has been proposed as a mediator of $A \beta-$ membrane surface interactions (Simakova and Arispe 2007). MD modeling (Davis and Berkowitz 2009a,b) suggests the induction of subtle changes in conformation around the $\beta$-turn of $A \beta$ fold on its membrane binding, and in vitro studies show the effect of $\mathrm{pH}$ and the protonation of His13 and/or His14 when the amphiphilic domain $A \beta_{11-22}$ is used for membrane binding studies (Ravault et al. 2009). Using Land D-handed enantiomers of $A \beta_{42}$, Ciccotosto et al. (2011) have reported that synthetic $A \beta$ binds directly to cell membranes in vivo through phosphatidylserine and that this interaction is stereospecific. The toxicity of $A \beta$ oligomers may therefore be related in part to some aspect of its specific electrostatic interactions with phosphatidylserine. Gangliosides provide another charged interactor for $A \beta$ on the cell surface (Nakazawa et al. 2009; Peters et al. 2009; Utsumi et al. 2009; Yagi-Utsumi et al. 2010), with potential effects on the folding pattern of the peptide (Mao et al. 2010; Ogawa et al. 2011).

\section{Hydrophobic Interactions of $A \beta$}

After the release of the $A \beta$ monomer from its partially transmembrane location, a portion of resultant $A \beta$ assemblies may bind and re-insert into the hydrophobic lipid bilayer. There has been a longstanding controversy in the field as to whether this re-insertion event leads to the formation of a complete transmembrane pore or whether membrane association and partial insertion can disrupt the bilayer to such an extent that its structural integrity is compromised. MD simulations and in vitro artificial lipid membrane models of this insertional event are plentiful (Friedman et al. 2009; Lemkul and Bevan 2009; Miyashita et al. 2009; Qiu et al. 2009; Song et al. 2009; Yang et al. 2009a,b; Morita et al. 2010; Schauerte et al. 2010; Wang et al. 2010), but rigorous evidence for a hydrophobic membrane-traversing interaction in vivo is lacking. Using photobleaching Förster resonance energy transfer, there was a loss of signal from the hydrophobic carboxyl terminus of $A \beta$ as it interacts with the plasma membrane of PC12 cells, which may indicate its sequestration within the lipid bilayer (Bateman and Chakrabartty 2009). Addition of synthetic $A \beta_{42}$ oligomers to N2a and HT22 neuronal cell lines led to significant cellular stiffening/rigidity (Lulevich et al. 2010). Peripheral membrane association of $A \beta_{42}$ (but not $A \beta_{40}$ ) oligomers with lysosmes has also been suggested as evidence of in vivo membrane insertion (Liu et al. 2010b). Clearly, more evidence is required to prove actual transmembrane insertion of the peptide in vivo.

\section{$\mathrm{A} \beta$ Interaction with Lipoproteins}

Electrostatic or hydrophobic interactions of $A \beta$ with the various lipoprotein particles (ApoE, ApoA, ApoJ) are discussed elsewhere in this 
Biochemistry of Amyloid $\beta$-Protein and Amyloid Deposits in AD

volume (Holtzman et al. 2011). We note in vivo evidence of direct ApoE-A $\beta$ and ApoA1-A $\beta$ interactions (Bales et al. 2009; Paula-Lima et al. 2009), and that ApoE found in the brain is more heavily sialylated than that in the peripheral circulation (Kawasaki et al. 2009), potentially facilitating electrostatic interactions with $\mathrm{A} \beta$ (see above).

\section{$A \beta$ Interactions with Selected Membrane Polypeptides (e.g., NMDA and ACh Receptors)}

Growing evidence suggests the occurrence of at least functional-if not physical-interactions of $A \beta$ oligomers with NMDA or $\alpha 7$-nicotinic ACh receptors or the cellular prion protein ( $\mathrm{Hu}$ et al. 2009; Lauren et al. 2009; Li et al. 2009; Liu et al. 2009b; Zhang et al. 2009b). However, much of this evidence comes from studies showing that antagonists or downstream regulators of these and other cell-surface receptors (e.g., AMPA and insulin receptors) can mitigate or fully prevent the effects of soluble $A \beta$ oligomers on synaptic form and function (see, e.g., Shankar et al. 2007; Li et al. 2009). Such studies only indicate that the expression and normal function of the receptor in question is necessary for some of the downstream effects of $A \beta$ on neurons to occur, not that these cellsurface polypeptides are the direct receptors for $A \beta$ in vivo. Instead, the binding of extracellular A $\beta$ oligomers-via their exposed hydrophobic residues - to certain lipids in the plasma membrane could alter the biophysical properties of the bilayer and secondarily and somewhat nonspecifically perturb the structures (and thus the functions) of a variety of membrane-anchored neuronal receptor proteins. Moreover, as mentioned above, the high concentrations of $\mathrm{Zn}^{2+}$ and $\mathrm{Cu}^{2+}$ found in and around NMDAR-containing post-synaptic elements may be involved in the actions of $A \beta$ oligomers at the membrane.

\section{Other $\mathrm{A} \beta$ Interactions}

Over the past 30 years, many other proteins have been described as being associated with $\mathrm{A} \beta$ extracellular deposits, using a variety of immunohistochemical or biochemical approaches. Among these, two broad categories of proteins stand out: extracellular matrix factors and inflammatory/stress response factors. The latter include members of the complement cascade, cytokines, immunoglobulins, acute phase proteins, components of the inflammosome, etc. The serine protease inhibitor, $\alpha 1$ antichymotrypsin, is an acute phase protein that may be tightly associated with amyloid plaque cores (Abraham et al. 1988). Biochemical isolation approaches have also yielded copurifying proteins of unknown pathogenic significance, e.g., a fragment (residues 60-95) of the neuronal protein, $\alpha$-synuclein, namely, its NAC peptide (i.e., "non-amyloid component" of plaques). The fact that some cortical neurons in $\mathrm{AD}$ accumulate aggregates of $\alpha$-synuclein (Lewy bodies and neurites) provides a possible explanation for the co-purification of this protein fragment from homogenized $\mathrm{AD}$ cortex. Many other polypeptides of unknown mechanistic importance in the disease pathogenesis could be cited here. The fact that some amyloid-associated proteins differ in their primary sequences and amounts between human and mouse brain could help explain why APP transgenic mice deposit plaques of human $\mathrm{A} \beta$ but not always with the same local associations and consequences (e.g., without significant neuronal loss).

\section{CONCLUSIONS}

Even the wealth of details and accompanying references that we have discussed above cannot do the subject of A $\beta$ biochemistry justice. Since Glenner and Wong's seminal paper in 1984, innumerable studies of this small, hydrophobic, and potentially lethal protein have been published. Indeed, several important aspects of its biology, including its mechanisms of formation (Haass et al. 2011) and clearance (Saido and Leissring 2011) and its measurement by brain imaging (Johnson et al. 2011) and in biological fluids (Blennow et al. 2011), are covered extensively in other parts of this volume. The genetics of dominantly inherited AD and the pathobiology of the apolipoprotein $\varepsilon 4$ allele in AD have 
combined to give $A \beta$ an apparent initiating role in at least some forms of the AD syndrome. Because these familial forms are largely indistinguishable from "sporadic" late-onset $\mathrm{AD}$, parsimony suggests that an imbalance between $\mathrm{A} \beta$ production and clearance-an $\mathrm{A} \beta$ dyshomeostasis-is a driving force for many or all cases of $\mathrm{AD}$ as we define this eponymic syndrome. And yet, precisely why $A \beta$ accumulates and what upstream events can lead to this accumulation remains unknown for the majority of cases of the disease. Perhaps only through the results of clinical trials of agents that must be working solely on $A \beta$ (e.g., highly specific anti-A $\beta$ antibodies) can we adequately test the theory that $A \beta$ accumulation is a central pathogenic event in $\mathrm{AD}$. For the sake of our patients and their families, one can only hope that the answer to this provocative question lies not too far in the future.

\section{REFERENCES}

${ }^{*}$ Reference is also in this collection.

Abraham CR, Selkoe DJ, Potter H. 1988. Immunochemica identification of the serine protease inhibitor, $\alpha_{1}$-antichymotrypsin in the brain amyloid deposits of Alzheimer's disease. Cell 52: 487-501.

Ahmed M, Davis J, Aucoin D, Sato T, Ahuja S, Aimoto S, Elliott JI, Van Nostrand WE, Smith SO. 2010. Structural conversion of neurotoxic amyloid- $\beta_{1-42}$ oligomers to fibrils. Nat Struct Mol Biol 17: 561-567.

Allsop D, Landon M, Kidd M. 1983. The isolation and amino acid composition of senile plaque core protein. Brain Res 259: 348-352.

Bales KR, Liu F, Wu S, Lin SZ, Koger D, DeLong C, Hansen JC, Sullivan PM, Paul SM. 2009. Human APOE isoformdependent effects on brain $\beta$-amyloid levels in PDAPP transgenic mice. J Neurosci 29: 6771-6779.

Barman A, Taves W, Prabhakar R. 2009. Insights into the mechanism of methionine oxidation catalyzed by metal $\left(\mathrm{Cu}^{2+}, \mathrm{Zn}^{2+}\right.$, and Fe $\left.{ }^{3+}\right)$-amyloid beta $(\mathrm{A} \beta)$ peptide complexes: A computational study. J Comput Chem 30: 1405-1413.

Baruch-Suchodolsky R, Fischer B. 2009. A $\beta_{40}$, either soluble or aggregated, is a remarkably potent antioxidant in cellfree oxidative systems. Biochemistry 48: 4354-4370.

Bateman DA, Chakrabartty A. 2009. Two distinct conformations of $A \beta$ aggregates on the surface of living PC12 cells. Biophys J 96: 4260-4267.

Behbehani GR, Mirzaie M. 2009. A high performance method for thermodynamic study on the binding of copper ion and glycine with Alzheimer's amyloid $\beta$ peptide. J Therm Anal Calorim 96: 631-635.
Bernstein SL, Dupuis NF, Lazo ND, Wyttenbach T, Condron MM, Bitan G, Teplow DB, Shea J-E, Ruotolo BT, Robinson $\mathrm{CV}$, et al. 2009. Amyloid- $\beta$ protein oligomerization and the importance of tetramers and dodecamers in the aetiology of Alzheimer's disease. Nat Chem 1: 326-331.

* Blennow K, Zetterberg H, Fagan AM. 2011. Fluid biomarkers in Alzheimer disease. Cold Spring Harb Perspect Med doi: 10.1101/cshperspect.a006221.

Brorsson AC, Bolognesi B, Tartaglia GG, Shammas SL, Favrin G, Watson I, Lomas DA, Chiti F, Vendruscolo M, Dobson CM, et al. 2010. Intrinsic determinants of neurotoxic aggregate formation by the amyloid $\beta$ peptide. Biophys J 98: $1677-1684$.

Brzyska M, Trzesniewska K, Wieckowska A, Szczepankiewicz A, Elbaum D. 2009. Electrochemical and conformational consequences of copper ( $\mathrm{Cu}-\mathrm{I}$ and $\mathrm{Cu}-\mathrm{II}$ ) binding to $\beta$-amyloid(1-40). Chembiochem 10: $1045-$ 1055.

Butterfield DA, Galvan V, Lange MB, Tang H, Sowell RA, Spilman P, Fombonne J, Gorostiza O, Zhang J, Sultana $\mathrm{R}$, et al. 2010. In vivo oxidative stress in brain of Alzheimer disease transgenic mice: Requirement for methionine 35 in amyloid $\beta$-peptide of APP. Free Radic Biol Med 48: $136-144$.

Caspar DL. 2009. Inconvenient facts about pathological amyloid fibrils. Proc Natl Acad Sci 106: 20555-20556.

Castano EM, Ghiso J, Prelli F, Gorevic PD, Migheli A, Frangione B. 1986. In vitro formation of amyloid fibrils from two synthetic peptides of different lengths homologous to Alzheimer's disease $\beta$-protein. Biochem Biophys Res Commun 141: 782-789.

Chebaro Y, Mousseau N, Derreumaux P. 2009. Structures and thermodynamics of Alzheimer's amyloid- $\beta$ $A \beta(16-35)$ monomer and dimer by replica exchange molecular dynamics simulations: Implication for fulllength $A \beta$ fibrillation. J Phys Chem B 113: 7668-7675.

Chi EY, Frey SL, Winans A, Lam KLH, Kjaer K, Majewski J, Lee KYC. 2010. Amyloid- $\beta$ fibrillogenesis seeded by interface-induced peptide misfolding and self-assembly. Biophys J 98: 2299-2308.

Ciccotosto GD, Tew DJ, Drew SC, Smith DG, Johanssen T, Lal V, Lau TL, Perez K, Curtain CC, Wade JD, et al. 2011. Stereospecific interactions are necessary for Alzheimer disease amyloid- $\beta$ toxicity. Neurobiol Aging 32: 235-248.

Cirrito JR, Yamada KA, Finn MB, Sloviter RS, Bales KR, May PC, Schoepp DD, Paul SM, Mennerick S, Holtzman DM. 2005. Synaptic activity regulates interstitial fluid amyloid- $\beta$ levels in vivo. Neuron 48: 913-922.

Cirrito JR, Kang JE, Lee J, Stewart FR, Verges DK, Silverio LM, Bu G, Mennerick S, Holtzman DM. 2008. Endocytosis is required for synaptic activity-dependent release of amyloid-beta in vivo. Neuron 58: 42-51.

Cizas P, Budvytyte R, Morkuniene R, Moldovan R, Broccio M, Losche M, Niaura G, Valincius G, Borutaite V. 2010. Size-dependent neurotoxicity of $\beta$-amyloid oligomers. Arch Biochem Biophy 496: 84-92.

Crouch PJ, Hung LW, Adlard PA, Cortes M, Lal V, Filiz G, Perez KA, Nurjono $\mathrm{M}$, Caragounis $\mathrm{A}, \mathrm{Du} \mathrm{T}$, et al. 2009a. Increasing $\mathrm{Cu}$ bioavailability inhibits $A \beta$ oligo- 
Biochemistry of Amyloid $\beta$-Protein and Amyloid Deposits in AD

mers and tau phosphorylation. Proc Natl Acad Sci 106: $381-386$.

Crouch PJ, Tew DJ, Du T, Nguyen DN, Caragounis A, Filiz G, Blake RE, Trounce IA, Soon CPW, Laughton K, et al. 2009b. Restored degradation of the Alzheimer's amyloid- $\beta$ peptide by targeting amyloid formation. J Neurochem 108: 1198-1207.

D’Arrigo C, Tabaton M, Perico A. 2009. N-terminal truncated pyroglutamyl $\beta$ amyloid peptide $A \beta p y 3-42$ shows a faster aggregation kinetics than the full-length $\mathrm{A} \beta 1-42$. Biopolymers 91: 861-873.

da Silva GFZ, Lykourinou VAngerhofer A, L-J Ming. 2009. Methionine does not reduce $\mathrm{Cu}(\mathrm{II})$ - $\beta$-amyloid!-Rectification of the roles of methionine-35 and reducing agents in metal-centered oxidation chemistry of $\mathrm{Cu}$ (II)$\beta$-amyloid. Biochim Biophy Acta 1792: 49-55.

Damante CA, Osz K, Nagy Z, Pappalardo G, Grasso G, Impellizzeri G, Rizzarelli E, Sovago I. 2009. Metal loading capacity of $A \beta \mathrm{N}$-terminus: a combined potentiometric and spectroscopic study of zinc(II) complexes with $\mathrm{A} \beta(1-16)$, its short or mutated peptide fragments and its polyethylene glycol-ylated analogue. Inorg Chem 48: 10405-10415.

Davis CH, Berkowitz ML. 2009a. Interaction between amyloid- $\beta$ (1-42) peptide and phospholipid bilayers: A molecular dynamics study. Biophys J 96: 785-797.

Davis CH, Berkowitz ML. 2009b. Structure of the amyloid$\beta$ (1-42) monomer absorbed to model phospholipid bilayers: A molecular dynamics study. J Phys Chem B 113: $14480-14486$.

Davis TJ, Soto-Ortega DD, Kotarek JA, Gonzalez-Velasquez FJ, Sivakumar K, Wu LY, Wang Q, Moss MA. 2009. Comparative study of inhibition at multiple stages of amyloid$\beta$ self-assembly provides mechanistic insight. Mol Pharmacol 76: 405-413.

De Ferrari GV, Canales MA, Shin I, Weiner LM, Silman I, Inestrosa NC. 2001. A structural motif of acetylcholinesterase that promotes amyloid $\beta$-peptide fibril formation. Biochemistry 40: 10447-10457.

Deshpande A, Kawai H, Metherate R, Glabe CG, Busciglio J. 2009. A role for synaptic zinc in activity-dependent $A \beta$ oligomer formation and accumulation at excitatory synapses. J Neurosci 29: 4004-4015.

Di Carlo M. 2010. Beta amyloid peptide: From different aggregation forms to the activation of different biochemical pathways. Eur Biophys J Biophys Lett 39: 877-888.

Dickens MG, Franz KJ. 2010. A prochelator activated by hydrogen peroxide prevents metal-induced amyloid $\beta$ aggregation. Chembiochem 11: 59-62.

Ding H, Wong PT, Lee EL, Gafni A, Steel DG. 2009. Determination of the oligomer size of amyloidogenic protein $\beta$-amyloid (1-40) by single-molecule spectroscopy. Biophys J 97: 912-921.

Dorlet P, Gambarelli S, Faller P, Hureau C. 2009. Pulse EPR spectroscopy reveals the coordination sphere of copper(II) ions in the 1-16 amyloid- $\beta$ peptide: A key role of the first two N-terminus residues. Angew Chem Int Ed Engl 48: 9273-9276.

Drew SC, Masters CL, Barnham KJ. 2009a. Alanine-2 carbonyl is an oxygen ligand in $\mathrm{Cu}^{2+}$ coordination of Alzheimer's disease amyloid- $\beta$ peptide—relevance to $\mathrm{N}$ - terminally truncated forms. J Am Chem Soc 131: 8760-8761.

Drew SC, Noble CJ, Masters CL, Hanson GR, Barnham KJ. 2009b. Pleomorphic copper coordination by Alzheimer's disease amyloid- $\beta$ peptide. J Am Chem Soc 131: 11951207.

Drochioiu G, Manea M, Dragusanu M, Murariu M, Dragan ES, Petre BA, Mezo G, Przybylski M. 2009. Interaction of $\beta$-amyloid (1-40) peptide with pairs of metal ions: An electrospray ion trap mass spectrometric model study. Biophys Chem 144: 9-20.

Duce JA, Tsatsanis A, Cater MA, James SA, Robb E, Wikhe K, Leong SL, Perez K, Johanssen T, Greenough MA, et al. 2010. Iron-export ferroxidase activity of $\beta$-amyloid precursor protein is inhibited by zinc in Alzheimer's disease. Cell 142: 857-867.

Edwin NJ, Hammer RP, McCarley RL, Russo PS. 2010. Reversibility of $\beta$-amyloid self-assembly: Effects of $\mathrm{pH}$ and added salts assessed by fluorescence photobleaching recovery. Biomacromolecules 11: 341-347.

Eisele YS, Bolmont T, Heikenwalder M, Langer F, Jacobson LH, Yan ZX, Roth K, Aguzzi A, Staufenbiel M, Walker LC, et al. 2009. Induction of cerebral $\beta$-amyloidosis: Intracerebral versus systemic $\mathrm{A} \beta$ inoculation. Proc Natl Acad Sci 106: 12926-12931.

Eisele YS, Obermüller U, Heilbronner G, Baumann F, Kaeser SA, Wolburg H, Walker LC, Staufenbiel M, Heikenwalder M, Jucker M. 2010. Peripherally applied $A \beta$-containing inoculates induce cerebral $\beta$-amyloidosis. Science 330: 980-982.

Englund H, Degerman Gunnarsson M, Brundin RM, Hedlund M, Kilander L, Lannfelt L, Pettersson FE. 2009. Oligomerization partially explains the lowering of A $\beta 42$ in Alzheimer's disease cerebrospinal fluid. Neurodegener Dis 6: 139-147.

Faller P. 2009. Copper and zinc binding to amyloid- $\beta$ : Coordination, dynamics, aggregation, reactivity and metalion transfer. Chembiochem 10: 2837-2845.

Feng Y, Wang XP, Yang SG, Wang YJ, Zhang X, Du XT, Sun XX, Zhao M, Huang L, Liu RT. 2009. Resveratrol inhibits beta-amyloid oligomeric cytotoxicity but does not prevent oligomer formation. Neurotoxicology 30: 986995.

Finder VH, Vodopivec I, Nitsch RM, Glockshuber R. 2010. The recombinant amyloid- $\beta$ peptide $A \beta 1-42$ aggregates faster and is more neurotoxic than synthetic $A \beta 1-42$. $J$ Mol Biol 396: 9-18.

Friede RL. 1965. Enzyme histochemical studies of senile plaques. J Neuropathol Exp Neurol 24: 477-491.

Friedman R, Pellarin R, Caflisch A. 2009. Amyloid aggregation on lipid bilayers and its impact on membrane permeability. J Mol Biol 387: 407-415.

Fu ZM, Luo Y, Derreumaux P, Wei GH. 2009. Induced $\beta$-barrel formation of the Alzheimer's A $\beta 25-35$ oligomers on carbon nanotube surfaces: Implication for amyloid fibril inhibition. Biophys J 97: 1795-1803.

Fukumoto H, Tokuda T, Kasai T, Ishigami N, Hidaka H, Kondo M, Allsop D, Nakagawa M. 2010. High-molecular-weight $\beta$-amyloid oligomers are elevated in cerebrospinal fluid of Alzheimer patients. FASEB J 24: $2716-2726$. 
Games D, Adams D, Alessandrini R, Barbour R, Berthelette P, Blackwell C, Carr T, Clemens J, Donaldson T, Gillespie F, et al. 1995. Alzheimer-type neuropathology in transgenic mice overexpressing V717F $\beta$-amyloid precursor protein. Nature 373: 523-527.

Gardberg A, Dice L, Pridgen K, Ko J, Patterson P, Ou S, Wetzel R, Dealwis C. 2009. Structures of A 3 -related peptide-monoclonal antibody complexes. Biochemistry 48: 5210-5217.

Glenner GG. 1979. Congophilic microangiopathy in the pathogenesis of Alzheimer's syndrome (presenile dementia). Med Hypotheses 5: 1231-1236.

Glenner GG, Wong CW. 1984a. Alzheimer's disease and Down's syndrome: Sharing of a unique cerebrovascular amyloid fibril protein. Biochem Biophys Res Commun 122: $1131-1135$.

Glenner GG, Wong CW. 1984b. Alzheimer's disease: Initial report of the purification and characterization of a novel cerebrovascular amyloid protein. Biochem Biophys Res Commun 120: 885-890.

Gorevic P, Goni F, Pons-Estel B, Alvarez F, Peress R, Frangione B. 1986. Isolation and partial characterization of neurofibrillary tangles and amyloid plaque cores in Alzheimer's disease: Immunohistological studies. J Neuropathol Exp Neurol 45: 647-664.

Grimaldi M, Scrima M, Esposito C, Vitiello G, Ramunno A, Limongelli V, D’Errico G, Novellino E, D'Ursi AM. 2010. Membrane charge dependent states of the $\beta$-amyloid fragment $A \beta \quad(16-35)$ with differently charged micelle aggregates. Biochim Biophys Acta 1798: 660-671.

Haass C, Selkoe DJ. 2007. Soluble protein oligomers in neurodegeneration: Lessons from the Alzheimer's amyloid $\beta$-peptide. Nat Rev Mol Cell Biol 8: 101-112.

* Haass C, Kaether C, Sisodia S, Thinakaran G. 2011. Trafficking and proteolytic processing of APP. Cold Spring Harb Perspect Med doi: 10.1101/cshperspect.a006270.

Haeffner F, Barnham KJ, Bush AI, Brinck T. 2010. Generation of soluble oligomeric $\beta$-amyloid species via copper catalyzed oxidation with implications for Alzheimer's disease: A DFT study. J Mol Model 16: 1103-1108.

Hamaguchi T, Ono K, Murase A, Yamada M. 2009. Phenolic compounds prevent Alzheimer's pathology through different effects on the amyloid- $\beta$ aggregation pathway. Am J Pathol 175: 2557-2565.

Hamley IW, Nutt DR, Brown GD, Miravet JF, Escuder B, Rodriguez-Llansola F. 2010. Influence of the solvent on the self-assembly of a modified amyloid beta peptide fragment. II. NMR and computer simulation investigation. J Phys Chem B 114: 940-951.

Harper JD, Wong SS, Lieber CM., Lansbury PT Jr. 1997. Observation of metastable $A \beta$ amyloid protofibrils by atomic force microscopy. Chem Biol 4: 119-125.

Hawkes CA, Deng LH, Shaw JE, Nitz M, McLaurin J. 2010. Small molecule $\beta$-amyloid inhibitors that stabilize protofibrillar structures in vitro improve cognition and pathology in a mouse model of Alzheimer's disease. Eur J Neurosci 31: 203-213.

Hellstrand E, Sparr E, Linse S. 2010. Retardation of A $\beta$ fibril formation by phospholipid vesicles depends on membrane phase behavior. Biophys J 98: 2206-2214.
* Holtzman D, Herz J, Bu Guojun. 2011. Apolipoprotein E and apolipoprotein E receptors: Normal biology and roles in Alzheimer disease. Cold Spring Harb Perspect Med doi: 10.1101/cshperspect.a006312.

Horn AH, Sticht H. 2010. Amyloid- $\beta 42$ oligomer structures from fibrils: A systematic molecular dynamics study. $J$ Phys Chem B 114: 2219-2226.

Hsiao K, Chapman P, Nilsen S, Ekman C, Harigaya Y, Younkin S, Yang F, Cole G. 1996. Correlative memory deficits, $\mathrm{A} \beta$ elevation, and amyloid plaques in transgenic mice. Science 274: 99-102.

Hu NW, Klyubin I, Anwy R, Rowan MJ. 2009. GluN2B subunit-containing NMDA receptor antagonists prevent $\mathrm{A} \beta$-mediated synaptic plasticity disruption in vivo. Proc Natl Acad Sci 106: 20504-20509.

Hureau C, Balland V, Coppel Y, Solari PL, Fonda E, Faller P. 2009a. Importance of dynamical processes in the coordination chemistry and redox conversion of copper amyloid- $\beta$ complexes. J Biol Inorg Chem 14: 995-1000.

Hureau C, Coppel Y, Dorlet P, Solari PL, Sayen S, Guillon E, Sabater L, Faller P. 2009b. Deprotonation of the Asp1-Ala2 peptide bond induces modification of the dynamic copper(II) environment in the amyloid- $\beta$ peptide near physiological pH. Angew Chem Int Ed Engl 48: 9522-9525.

Jiang D, Li X, Williams R, Patel S, Men L, Wang Y, Zhou F. 2009a. Ternary complexes of iron, amyloid- $\beta$, and nitrilotriacetic acid: Binding affinities, redox properties, and relevance to iron-induced oxidative stress in Alzheimer's disease. Biochemistry 48: 7939-7947.

Jiang DL, Dinh KL, Ruthenburg TC, Zhang Y, Su L, Land DP, Zhou FM. 2009b. A kinetic model for $\beta$-amyloid adsorption at the air/solution interface and its implication to the $\beta$-amyloid aggregation process. J Phys Chem B 113: 3160-3168.

Jiang DL, Li XJ, Liu L, Yagnik GB, Zhou FM. 2010. Reaction rates and mechanism of the ascorbic acid oxidation by molecular oxygen facilitated by $\mathrm{Cu}(\mathrm{II})$-containing amyloid- $\beta$ complexes and aggregates. J Phys Chem B 114: 4896-4903.

Jin M, Shepardson N, Yang T, Walsh D, Selkoe D. 2011. Soluble amyloid $\beta$-protein dimers isolated from Alzheimer cortex directly induce Tau hyperphosphorylation and neuritic degeneration. Proc Natl Acad Sci 108: 5819-5824.

* Johnson KA, Fox NC, Sperling RA, Klunk WE. 2011. Brain imaging in Alzheimer disease. Cold Spring Harb Perspect Med doi: 10.1101/cshperspect.a006213.

Jun S, Gillespie JR, Shin BK, Saxena S. 2009. The second $\mathrm{Cu}(\mathrm{II})$-binding site in a proton-rich environment interferes with the aggregation of amyloid- $\beta(1-40)$ into amyloid fibrils. Biochemistry 48: 10724-10732.

Kaether C, Schmitt S, Willem M, Haass C. 2006. Amyloid precursor protein and Notch intracellular domains are generated after transport of their precursors to the cell surface. Traffic 7: 408-415.

Kajava AV, Baxa U, Steven AC. 2010. $\beta$ arcades: Recurring motifs in naturally occurring and disease-related amyloid fibrils. FASEB J 24: 1311-1319.

Kang J, Lemaire H-G, Unterbeck A, Salbaum JM, Masters CL, Grzeschik K-H, Multhaup G, Beyreuther K, MullerHill B. 1987. The precursor of Alzheimer's disease 
Biochemistry of Amyloid $\beta$-Protein and Amyloid Deposits in AD

amyloid A4 protein resembles a cell-surface receptor. Nature 325: 733-736.

Kawarabayashi T, Younkin LH, Saido TC, Shoji M, Ashe KH, Younkin SG. 2001. Age-dependent changes in brain, CSF, and plasma amyloid $\beta$ protein in the Tg2576 transgenic mouse model of Alzheimer's disease. J Neurosci 21: $372-381$.

Kawasaki K, Ogiwara N, Sugano M, Okumura N, Yamauchi K. 2009. Sialic acid moiety of apolipoprotein $\mathrm{E}$ and its impact on the formation of lipoprotein particles in human cerebrospinal fluid. Clin Chim Acta 402: 61-66.

Kayed R, Pensalfini A, Margol L, Sokolov Y, Sarsoza F, Head E, Hall J, Glabe C. 2009. Annular protofibrils are a structurally and functionally distinct type of amyloid oligomer. J Biol Chem 284: 4230-4237.

Kirschner DA, Inouye H, Duffy LK, Sinclair A, Lind M, Selkoe DJ. 1987. Synthetic peptide homologous to $\beta$ protein from Alzheimer disease forms amyloid-like fibrils in vitro. Proc Natl Acad Sci 84: 6953-6957.

Koffie RM, Meyer-Luehmann M, Hashimoto T, Adams KW, Mielke ML, Garcia-Alloza M, Micheva KD, Smith SJ, Kim ML, Lee VM, et al. 2009. Oligomeric amyloid $\beta$ associates with postsynaptic densities and correlates with excitatory synapse loss near senile plaques. Proc Natl Acad Sci 106: 4012-4017.

Kotarek JA, Moss MA. 2010. Impact of phospholipid bilayer saturation on amyloid- $\beta$ protein aggregation intermediate growth: A quartz crystal microbalance analysis. Anal Biochem 399: 30-38.

Ladiwala AR, Lin JC, Bale SS, Marcelino-Cruz AM, Bhattacharya M, Dordick JS, Tessier PM. 2010. Resveratrol selectively remodels soluble oligomers and fibrils of amyloid $A \beta$ into off-pathway conformers. J Biol Chem 285: $24228-24237$.

* LaFerla F, Duff K. 2011. Animal models of Alzheimer disease. Cold Spring Harb Perspect Med doi: 10.1101/ cshperspect.a006320.

Lambert MP, Barlow AK, Chromy BA, Edwards C, Freed R, Iosatos M, Morgan TE, Rozovsky I, Trommer B, Viola KL, et al. 1998. Diffusible, nonfribrillar ligands derived from $A \beta_{1-42}$ are potent central nervous system neurotoxins. Proc Natl Acad Sci 95: 6448-6453.

Laurén J, Gimbel DA, Nygaard HB, Gilbert JW, Strittmatter SM. 2009. Cellular prion protein mediates impairment of synaptic plasticity by amyloid- $\beta$ oligomers. Nature 457 : $1128-1132$.

Lemkul JA Bevan DR. 2009. Perturbation of membranes by the amyloid $\beta$-peptide-a molecular dynamics study. FEBS J 276: 3060-3075.

Lesné S, Koh MT, Kotilinek L, Kayed R, Glabe CG, Yang A, Gallagher M, Ashe KH. 2006. A specific amyloid- $\beta$ protein assembly in the brain impairs memory. Nature 440: 352-357.

Lesné S, Sherman MA, Handoka MA, Schneider JA, Bennett DA, Ashe KH. 2009. Distinct brain A $\beta$ oligomers are associated with different stages of Alzheimer's disease. Soc Neurosci (Abstr 62720).

Li S, Hong S, Shepardson NE, Walsh DM, Shankar GM, Selkoe D. 2009. Soluble oligomers of amyloid $\beta$ protein facilitate hippocampal long-term depression by disrupting neuronal glutamate uptake. Neuron 62: 788-801.
Li H, Monien BH, Fradinger EA, Urbanc B, Bitan G. 2010. Biophysical characterization of $A \beta 42$ C-terminal fragments: Inhibitors of $\mathrm{A} \beta 42$ neurotoxicity. Biochemistry 49: $1259-1267$.

Liu L, Zhang L, Mao X, Niu L, Yang Y, Wang C. 2009a. Chaperon-mediated single molecular approach toward modulating $A \beta$ peptide aggregation. Nano Lett 9: 4066-4072.

Liu Q, Huang Y, Xue FQ, Simard A, DeChon J, Li G, Zhang JL, Lucero L, Wang M, Sierks M, et al. 2009b. A novel nicotinic acetylcholine receptor subtype in basal gorebrain cholinergic neurons with high sensitivity to amyloid peptides. J Neurosci 29: 918-929.

Lui JK, Laws SM, Li QX, Villemagne VL, Ames D, Brown B, Bush AI, De Ruyck K, Dromey J, Ellis KA, et al. 2010a. Plasma amyloid- $\beta$ as a biomarker in Alzheimer's disease: The AIBL study of aging. J Alzheimers Dis 20: 1233-1242.

Liu RQ, Zhou QH, Ji SR, Zhou Q, Feng D, Wu Y, Sui SF. 2010b. Membrane localization of $\beta$-amyloid $1-42$ in lysosomes: A possible mechanism for lysosome labilization. J Biol Chem 285: 19986-19996.

Lulevich V, Zimmer CC, Hong HS, Jin LW, Liu GY. 2010. Single-cell mechanics provides a sensitive and quantitative means for probing amyloid- $\beta$ peptide and neuronal cell interactions. Proc Natl Acad Sci 107: 13872-13877.

Ma XJ, Liu L, Mao XB, Niu L, Deng K, Wu WH, Li YM, Yang YL, Wang C. 2009. Amyloid $\beta$ (1-42) folding multiplicity and single-molecule binding behavior studied with STM. J Mol Biol 388: 894-901.

* Mandelkow E-M, Mandelkow E. 2011. Biochemistry and cell biology of Tau protein in neurofibrillary degeneration. Cold Spring Harb Perspect Med doi: 10.1101/ cshperspect.a006247.

Mao YL, Shang ZG, Imai Y, Hoshino T, Tero R, Tanaka M, Yamamoto N, Yanagisawa K, Urisu T. 2010. Surfaceinduced phase separation of a sphingomyelin/cholesterol/ganglioside GM1-planar bilayer on mica surfaces and microdomain molecular conformation that accelerates A $\beta$ oligomerization. Biochim Biophys Acta 1798: 1090-1099.

Masters CL, Simms G, Weinman NA, Multhaup G, McDonald BL, Beyreuther K. 1985. Amyloid plaque core protein in Alzheimer disease and Down syndrome. Proc Natl Acad Sci 82: 4245-4249.

Masuda Y, Uemura S, Ohashi R, Nakanishi A, Takegoshi K, Shimizu T, Shirasawa T, Irie K. 2009. Identification of physiological and toxic conformations in $\mathrm{A} \beta 42$ aggregates. Chembiochem 10: 287-295.

McDonald JM, Savva GM, Brayne C, Welzel AT, Forster G, Shankar GM, Selkoe DJ, Ince PG, Walsh DM, Medical Research Council Cognitive Function and Aging Study. 2010. The presence of sodium dodecyl sulphate-stable $\mathrm{A} \beta$ dimers is strongly associated with Alzheimer-type dementia. Brain 133: 1328-1341.

McLean CA, Cherny RA, Fraser FW, Fuller SJ, Smith MJ, Beyreuther K, Bush AI, Masters CL. 1999. Soluble pool of $A \beta$ amyloid as a determinant of severity of neurodegeneration in Alzheimer's disease. Ann Neurol 46: $860-866$.

Meyer-Luehmann M, Spires-Jones TL, Prada C, GarciaAlloza M, de Calignon A, Rozkalne A, KoenigsknechtTalboo J, Holtzman DM, Bacskai BJ, Hyman BT. 2008. 
C.L. Masters and D.J. Selkoe

Rapid appearance and local toxicity of amyloid- $\beta$ plaques in a mouse model of Alzheimer's disease. Nature 451: 720-724.

Miller Y, Ma BY, Nussinov R. 2009. Polymorphism of Alzheimer's $A \beta(17-42)$ (p3) oligomers: The importance of the turn location and its conformation. Biophys J 97: $1168-1177$.

Miller Y, Ma B, Nussinov R. 2010. Zinc ions promote Alzheimer $A \beta$ aggregation via population shift of polymorphic states. Proc Natl Acad Sci 107: 9490-9495.

Miyashita N, Straub JE, Thirumalai D. 2009. Structures of $\beta$-amyloid peptide $1-40,1-42$, and 1-55-the 672 726 fragment of APP-in a membrane environment with implications for interactions with gamma-secretase. $J$ Am Chem Soc 131: 17843-17852.

Moore BD, Rangachari V, Tay WM, Milkovic NM, Rosenberry TL. 2009. Biophysical analyses of synthetic amyloid- $\beta(1-42)$ aggregates before and after covalent cross-linking. Implications for deducing the structure of endogenous amyloid- $\beta$ oligomers. Biochemistry 48: 11796-11806.

Mori H, Takio K, Ogawara M, Selkoe DJ. 1992. Mass spectrometry of purified amyloid $\beta$ protein in Alzheimer's disease. J Biol Chem 267: 17082-17086.

Morinaga A, Hasegawa K, Nomura R, Ookoshi T, Ozawa D, Goto Y, Yamada M, Naiki H. 2010. Critical role of interfaces and agitation on the nucleation of $A \beta$ amyloid fibrils at low concentrations of $A \beta$ monomers. Biochim Biophy Acta 1804: 986-995.

Morita M, Vestergaard M, Hamada T, Takagi M. 2010. Realtime observation of model membrane dynamics induced by Alzheimer's amyloid beta. Biophys Chem 147: 81-86.

* Mucke L, Selkoe D. 2011. Neurotoxicity of amyloid $\beta$-protein: Synaptic and network dysfunction. Cold Spring Harb Perspect Med doi: 10.1101/cshperspect.a006338.

Murray MM, Bernstein SL, Nyugen V, Condron MM, Teplow DB, Bowers MT. 2009a. Amyloid $\beta$ protein: $A \beta 40$ inhibits $A \beta 42$ oligomerization. J Am Chem Soc 131: 6316-6317.

Murray MM, Krone MG, Bernstein SL, Baumketner A, Condron MM, Lazo ND, Teplow DB, Wyttenbach T, Shea JE, Bowers MT. 2009b. Amyloid $\beta$-protein: Experiment and theory on the 21-30 fragment. J Phys Chem B 113: 6041-6046.

Nakazawa Y, Suzuki Y, Williamson MP, Saito H, Asakura T. 2009. The interaction of amyloid $A \beta(1-40)$ with lipid bilayers and ganglioside as studied by ${ }^{31} \mathrm{P}$ solid-state NMR. Chem Phys Lipids 158: 54-60.

Negureanu L, Baumketner A. 2009. Microscopic factors that control $\beta$-sheet registry in amyloid fibrils formed by fragment 11-25 of amyloid $\beta$ peptide: Insights from computer simulations. J Mol Biol 389: 921-937.

Nerelius C, Sandegren A, Sargsyan H, Raunak R, Leijonmarck H, Chatterjee U, Fisahn A, Imarisio S, Lomas DA, Crowther DC, et al. 2009. $\alpha$-Helix targeting reduces amyloid- $\beta$ peptide toxicity. Proc Natl Acad Sci 106: 9191-9196.

Noguchi A, Matsumura S, Dezawa M, Tada M, Yanazawa M, Ito A, Akioka M, Kikuchi S, Sato M, Ideno S, et al. 2009. Isolation and characterization of patient-derived, toxic, high mass amyloid $\beta$-protein $(A \beta)$ assembly from Alzheimer disease brains. J Biol Chem 284: 32895-32905.

O'Nuallain B, Freir DB, Nicoll AJ, Risse E, Ferguson N, Herron CE, Collinge J, Walsh DM. 2010. Amyloid $\beta$-protein dimers rapidly form stable synaptotoxic protofibrils. J Neurosci 30: 14411-14419.

Ogawa M, Tsukuda M, Yamaguchi T, Ikeda K, Okada T, Yano Y, Hoshino M, Matsuzaki K. 2011. Ganglioside-mediated aggregation of amyloid $\beta$-proteins $(A \beta)$ : Comparison between $A \beta-(1-42)$ and $A \beta-(1-40)$. J Neurochem 116: 851-857.

Ogi H, Hatanaka K, Fukunishi Y, Nagai H, Hirao M, Nishiyama M. 2009. Aggregation behavior of amyloid $\beta_{1-42}$ peptide studied using $55 \mathrm{MHz}$ wireless-electrodeless quartz crystal microbalance-article no. 07GF01. Jpn J Appl Phys 48: doi: 10.1143/JJAP.48.07GF01.

Olofsson A, Lindhagen-Persson M, Vestling M, SauerEriksson AE, Öhman A. 2009a. Quenched hydrogen/ deuterium exchange NMR characterization of amyloid- $\beta$ peptide aggregates formed in the presence of $\mathrm{Cu}^{2+}$ or $\mathrm{Zn}^{2+}$. FEBS J 276: 4051-4060.

Olofsson A, Sauer-Eriksson AE, Öhman A. 2009b. Amyloid fibril dynamics revealed by combined hydrogen/deuterium exchange and nuclear magnetic resonance. Anal Biochem 385: 374-376.

Ono K, Condron MM, Teplow DB. 2009. Structure-neurotoxicity relationships of amyloid $\beta$-protein oligomers. Proc Natl Acad Sci 106: $14745-14750$.

Ono K, Condron MM, Teplow DB. 2010. Effects of the English (H6R) and Tottori (D7N) familial Alzheimer disease mutations on amyloid $\beta$-protein assembly and toxicity. J Biol Chem 285: 23186-23197.

Paparcone R, Buehler MJ. 2009. Microscale structural model of Alzheimer $A \beta(1-40)$ amyloid fibril-article no. 243904. Appl Phys Lett 94: 43904-43904.

Paravastu AK, Qahwash I, Leapman RD, Meredith SC, Tycko R. 2009. Seeded growth of $\beta$-amyloid fibrils from Alzheimer's brain-derived fibrils produces a distinct fibril structure. Proc Natl Acad Sci 106: 7443-7448.

Paula-Lima AC, Tricerri MA, Brito-Moreira J, Bomfim TR, Oliveira FF, Magdesian MH, Grinberg LT, Panizzutti R, Ferreira ST. 2009. Human apolipoprotein A-I binds amyloid- $\beta$ and prevents $A \beta$-induced neurotoxicity. Int J Biochem Cell Biol 41: 1361-1370.

Perálvarez-Marín A, Mateos L, Zhang C, Singh S, CedazoMinguez A, Visa N, Morozova-Roche L, Graslund A, Barth A. 2009. Influence of residue 22 on the folding, aggregation profile, and toxicity of the Alzheimer's amyloid $\beta$ peptide. Biophys J 97: 277-285.

Perreau VM, Orchard S, Adlard PA, Bellingham SA, Cappai R, Ciccotosto GD, Cowie TF, Crouch PJ, Duce JA, Evin G, et al. 2010. A domain level interaction network of amyloid precursor protein and $A \beta$ of Alzheimer's disease. Proteomics 10: 2377-2395.

Perrone L, Mothes E, Vignes M, Mockel A, Figueroa C, Miquel MC, Maddelein ML, Faller P. 2009. Copper transfer from $\mathrm{Cu}-\mathrm{A} \beta$ to human serum albumin inhibits aggregation, radical production and reduces $A \beta$ toxicity. Chembiochem 11: 110-118.

Peters I, Igbavboa U, Schütt T, Haidari S, Hartig U, Rosello X, Bottner S, Copanaki E, Deller T, Kogel D, et al. 2009. The interaction of beta-amyloid protein with cellular 
Biochemistry of Amyloid $\beta$-Protein and Amyloid Deposits in AD

membranes stimulates its own production. Biochim Biophys Acta 1788: 964-972.

Pham E, Crews L, Ubhi K, Hansen L, Adame A, Cartier A, Salmon D, Galasko D, Michael S, Savas JN, et al. 2010. Progressive accumulation of amyloid- $\beta$ oligomers in Alzheimer's disease and in amyloid precursor protein transgenic mice is accompanied by selective alterations in synaptic scaffold proteins. FEBS J 277: 3051-3067.

Philipson O, Hammarström P, Nilsson KPR, Portelius E, Olofsson T, Ingelsson M, Hyman BT, Blennow K, Lannfelt L, Kalimo H, et al. 2009. A highly insoluble state of $A \beta$ similar to that of Alzheimer's disease brain is found in Arctic APP transgenic mice. Neurobiol Aging 30: 1393-1405.

Picone P, Carrotta R, Montana G, Nobile MR, Biagio PLS, Di Carlo M. 2009. A $\beta$ oligomers and fibrillar aggregates induce different apoptotic pathways in LAN5 neuroblastoma cell cultures. Biophys J 96: 4200-4211.

Pitt J, Roth W, Lacor P, Smith AB, Blankenship M, Velasco P, De Felice F, Breslin P, Klein WL. 2009. Alzheimer'sassociated $A \beta$ oligomers show altered structure, immunoreactivity and synaptotoxicity with low doses of oleocanthal. Toxicol Appl Pharmacol 240: 189-197.

Qi-Takahara Y, Morishima-Kawashima M, Tanimura Y, Dolios G, Hirotani N, Horikoshi Y, Kametani F, Maeda M, Saido TC, Wang R, et al. 2005. Longer forms of amyloid $\beta$ protein: Implications for the mechanism of intramembrane cleavage by $\gamma$-secretase. J Neurosci 25: 436-445.

Qiu L, Lewis A, Como J, Vaughn MW, Huang J, Somerharju P, Virtanen J, Cheng KH. 2009. Cholesterol modulates the interaction of $\beta$-amyloid peptide with lipid bilayers. Biophys J 96: 4299-4307.

Rajendran R, Minqin R, Ynsa MD, Casadesus G, Smith MA, Perry G, Halliwell B, Watt F. 2009. A novel approach to the identification and quantitative elemental analysis of amyloid deposits-insights into the pathology of Alzheimer's disease. Biochem Biophys Res Commun 382: 91-95.

Ramos I, Fabris D, Qi W, Fernandez EJ, Good TA. 2009. Kinetic study of $\beta$-amyloid residue accessibility using reductive alkylation and mass spectrometry. Biotechnol Bioeng 104: 181-192.

Ravault S, Flore C, Saurel O, Milon A, Brasseur R, Lins L. 2009. Study of the specific lipid binding properties of A $\beta$ 11-22 fragment at endosomal pH. Langmuir 25: $10948-10953$.

Reddy G, Straub JE, Thirumalai D. 2009a. Influence of preformed Asp23-Lys28 salt bridge on the conformational fluctuations of monomers and dimers of $A \beta$ peptides with implications for rates of fibril formation. J Phys Chem B 113: 1162-1172.

Reddy G, Straubb JE, Thirumalai D. 2009b. Dynamics of locking of peptides onto growing amyloid fibrils. Proc Natl Acad Sci 106: 11948-11953.

Reinke AA, Seh HY, Gestwicki JE. 2009. A chemical screening approach reveals that indole fluorescence is quenched by pre-fibrillar but not fibrillar amyloid- $\beta$. Bioorg Med Chem Lett 19: 4952-4957.

Relini A, Cavalleri O, Rolandi R, Gliozzi A. 2009. The twofold aspect of the interplay of amyloidogenic proteins with lipid membranes. Chem Phys Lipids 158: 1-9.
Riviere C, Delaunay JC, Immel F, Cullin C, Monti JP. 2009. The polyphenol piceid destabilizes preformed amyloid fibrils and oligomers in vitro: Hypothesis on possible molecular mechanisms. Neurochem Res 34: 1120-1128.

Rodríguez-Rodríguez C, Sánchez de Groot N, Rimola A, Alvarez-Larena A, Lloveras V, Vidal-Gancedo J, Ventura S, Vendrell J, Sodupe M, González-Duarte P. 2009. Design, selection, and characterization of thioflavinbased intercalation compounds with metal chelating properties for application in Alzheimer's disease. J Am Chem Soc 131: 1436-1451.

Roher A, Wolfe D, Palutke M, KuKuruga D. 1986. Purification, ultrastructure, and chemical analyses of Alzheimer disease amyloid plaque core protein. Proc Natl Acad Sci 83: $2662-2666$.

Roher AE, Lowenson JD, Clarke S, Wolkow C, Wang R, Cotter RJ, Reardon I, Zürcher-Neely HA, Heinrikson RL, Ball MJ, et al. 1993. Structural alterations in the peptide backbone of $\beta$-amyloid core protein may account for its deposition and stability in Alzheimer's disease. J Biol Chem 268: $3072-3083$.

Roher AE, Esh CL, Kokjohn TA, Castaño EM, Van Vickle GD, Kalback WM, Patton RL, Luehrs DC, Daugs ID, Kuo YM, et al. 2009. Amyloid beta peptides in human plasma and tissues and their significance for Alzheimer's disease. Alzheimers Dement 5: 18-29.

Ryan DA, Narrow WC, Federoff HJ, Bowers WJ. 2010. An improved method for generating consistent soluble amyloid-beta oligomer preparations for in vitro neurotoxicity studies. J Neurosci Methods 190: 171-179.

Rózga M, Kłoniecki M, Dadlez M, Bal W. 2010. A direct determination of the dissociation constant for the $\mathrm{Cu}$ (II) complex of amyloid $\beta 1-40$ peptide. Chem Res Toxicol 23: 336-340.

Sahoo B, Nag S, Sengupta P, Maiti S. 2009. On the stability of the soluble amyloid aggregates. Biophys J 97: 14541460.

* Saido T, Leissring MA. 2011. Proteolytic degradation of amyloid $\beta$-protein. Cold Spring Harb Perspect Med doi: 10.1101/cshperspect.a006379.

Saido TC, Iwatsubo T, Mann DMA, Shimada H, Ihara Y, Kawashima S. 1995. Dominant and differential deposition of distinct $\beta$-amyloid peptide species, $A \beta_{\mathrm{N} 3(\mathrm{p} 3)}$, in senile plaques. Neuron 14: 457-466.

Sakono M, Zako T. 2010. Amyloid oligomers: Formation and toxicity of A $\beta$ oligomers. FEBS J 277: 1348-1358.

Salay LC, Qi W, Keshet B, Tamm LK, Fernandez EJ. 2009. Membrane interactions of a self-assembling model peptide that mimics the self-association, structure and toxicity of $\mathrm{A} \beta(1-40)$. Biochim Biophys Acta 1788: 1714-1721.

Sanders HM, Lust R, Teller JK. 2009. Amyloid-beta peptide $A \beta$ p3-42 affects early aggregation of full-length $A \beta$ 1-42. Peptides 30: 849-854.

Sarell CJ, Syme CD, Rigby SEJ, Viles JH. 2009. Copper(II) binding to amyloid- $\beta$ fibrils of Alzheimer's disease reveals a picomolar affinity: Stoichiometry and coordination geometry are independent of $A \beta$ oligomeric form. Biochemistry 48: 4388-4402.

Sargaeva NP, Lin C, O'Connor PB. 2009. Identification of aspartic and isoaspartic acid residues in amyloid $\beta$ 
peptides, including $A \beta 1-42$, using electron-ion reactions. Anal Chem 81: 9778-9786.

Schauerte JA, Wong PT, Wisser KC, Ding H, Steel DG, Gafni A. 2010. Simultaneous single-molecule fluorescence and conductivity studies reveal distinct classes of $A \beta$ species on lipid bilayers. Biochemistry 49: 3031-3039.

Schlenzig D, Manhart S, Cinar Y, Kleinschmidt M, Hause G, Willbold D, Funke SA, Schilling S, Demuth HU. 2009 Pyroglutamate formation influences solubility and amyloidogenicity of amyloid peptides. Biochemistry 48: 7072-7078.

Schmidt M, Sachse C, Richter W, Xu C, Fändrich M, Grigorieff N. 2009. Comparison of Alzheimer $A \beta(1-$ $40)$ and $A \beta(1-42)$ amyloid fibrils reveals similar protofilament structures. Proc Natl Acad Sci 106: 19813-19818.

Seifert F, Schulz K, Koch B, Manhart S, Demuth HU, Schilling S. 2009. Glutaminyl cyclases display significant catalytic proficiency for glutamyl substrates. Biochemistry 48: 11831-11833.

Selkoe DJ. 1994. Cell biology of the amyloid $\beta$-protein precursor and the mechanism of Alzheimer's disease. Ann Rev Cell Biol 10: 373-403.

Selkoe DJ, Abraham CR, Podlisny MB, Duffy LK. 1986. Isolation of low-molecular-weight proteins from amyloid plaque fibers in Alzheimer's disease. J Neurochem 146: $1820-1834$.

* Serrano-Pozo A, Frosch MP, Masliah E, Hyman BT. 2011 Neuropathological alterations in Alzheimer disease. Cold Spring Harb Perspect Med doi: 10.1101/cshperspect.a006189.

Sevalle J, Amoyel A, Robert P, Fournié-Zaluski MC, Roques B, Checler F. 2009. Aminopeptidase A contributes to the $\mathrm{N}$-terminal truncation of amyloid $\beta$-peptide. J Neurochem 109: 248-256.

Shankar GM, Bloodgood BL, Townsend M, Walsh DM, Selkoe DJ, Sabatini BL. 2007. Natural oligomers of the Alzheimer amyloid- $\beta$ protein induce reversible synapse loss by modulating an NMDA-type glutamate receptor-dependent signaling pathway. J Neurosci 27: 28662875.

Shankar GM, Li S, Mehta TH, Garcia-Munoz A, Shepardson NE, Smith I, Brett FM, Farrell MA, Rowan MJ, Lemere $C A$, et al. 2008. Amyloid- $\beta$ protein dimers isolated directly from Alzheimer's brains impair synaptic plasticity and memory. Nat Med 14: 837-842.

Shankar GM, Leissring MA, Adame A, Sun X, Spooner E, Masliah E, Selkoe DJ, Lemere CA, Walsh DM. 2009. Biochemical and immunohistochemical analysis of an Alzheimer's disease mouse model reveals the presence of multiple cerebral $A \beta$ assembly forms throughout life. Neurobiol Dis 36: 293-302.

Simakova O, Arispe NJ. 2007. The cell-selective neurotoxicity of the Alzheimer's $A \beta$ peptide is determined by surface phosphatidylserine and cytosolic ATP levels. Membrane binding is required for $\mathrm{A} \beta$ toxicity. J Neurosci 27: 13719-13729.

Smith DP, Ciccotosto GD, Tew DJ, Fodero-Tavoletti MT, Johanssen T, Masters CL, Barnham KJ, Cappai R. 2007. Concentration dependent $\mathrm{Cu} 2+$ induced aggregation and dityrosine formation of the Alzheimer's disease amyloid- $\beta$ peptide. Biochemistry 46: 2881-2891.
Smith NW, Annunziata O, Dzyuba SV. 2009. Amphotericin $B$ interactions with soluble oligomers of amyloid $A \beta$ 1-42 peptide. Bioorg Med Chem 17: 2366-2370.

Söderberg L, Bogdanovic N, Axelsson B, Winblad B, Näslund J, Tjernberg LO. 2006. Analysis of single Alzheimer solid plaque cores by laser capture microscopy and nanoelectrospray/tandem mass spectrometry. Biochemistry 45: 9849-9856.

Song HP, Ritz S, Knoll W, Sinner EK. 2009. Conformation and topology of amyloid $\beta$-protein adsorbed on a tethered artificial membrane probed by surface plasmon field-enhanced fluorescence spectroscopy. J Struct Biol 168: $117-124$.

Stoltenberg M, Bush AI, Bach G, Smidt K, Larsen A, Rungby J, Lund S, Doering P, Danscher G. 2007. Amyloid plaques arise from zinc-enriched cortical layers in APP/PS1 transgenic mice and are paradoxically enlarged with dietary zinc deficiency. Neuroscience 150: 357-369.

Streltsov VA, Varghese JN, Masters CL, Nuttall SD. 2011. Crystal structure of the amyloid- $\beta$ p3 fragment provides a model for oligomer formation in Alzheimer's disease. Neurosci 31: 1419-1426.

Sun X, Wu WH, Liu Q, Chen MS, Yu YP, Ma Y, Zhao YF, Li YM. 2009. Hybrid peptides attenuate cytotoxicity of $\beta$-amyloid by inhibiting its oligomerization: Implication from solvent effects. Peptides 30: 1282-1287.

Sureshbabu N, Kirubagaran R, Thangarajah H, Malar EJP, Jayakumar R. 2010. Lipid-induced conformational transition of amyloid $\beta$ peptide fragments. J Mol Neurosci 41: 368-382.

Takami M, Nagashima Y, Sano Y, Ishihara S, MorishimaKawashima M, Funamoto S, Ihara Y. 2009. $\gamma$-Secretase: Successive tripeptide and tetrapeptide release from the transmembrane domain of $\beta$-carboxyl terminal fragment. J Neurosci 29: 13042-13052.

Takeda T, Klimov DK. 2009a. Probing the effect of aminoterminal truncation for $\mathrm{A} \beta(1-40)$ peptides. J Phys Chem B 113: 6692-6702.

Takeda T, Klimov DK. 2009b. Replica exchange simulations of the thermodynamics of $A \beta$ fibril growth. Biophys J 96: $442-452$.

Takeda T, Klimov DK. 2009c. Side chain interactions can impede amyloid fibril growth: Replica exchange simulations of $A \beta$ peptide mutant. J Phys Chem B 113: $11848-11857$.

Takeda T, Klimov DK. 2010. Computational backbone mutagenesis of $A \beta$ peptides: Probing the role of backbone hydrogen bonds in aggregation. J Phys Chem $B$ 114: $4755-4762$.

Talmard C, Yona RL, Faller P. 2009. Mechanism of zinc(II)promoted amyloid formation: Zinc(II) binding facilitates the transition from the partially $\alpha$-helical conformer to aggregates of amyloid- $\beta$ protein(1-28). J Biol Inorg Chem 14: 449-455.

Taniguchi A, Sohma Y, Hirayama Y, Mukai H, Kimura T, Hayashi Y, Matsuzaki K, Kiso Y. 2009. "Click peptide": $\mathrm{pH}$-triggered in situ production and aggregation of monomer A $\beta$ 1-42. Chembiochem 10: 710-715.

Tomic JL, Pensalfini A, Head E, Glabe CG. 2009. Soluble fibrillar oligomer levels are elevated in Alzheimer's disease brain and correlate with cognitive dysfunction. Neurobiol Dis 35: 352-358. 
Biochemistry of Amyloid $\beta$-Protein and Amyloid Deposits in AD

Tomidokoro Y, Rostagno A, Neubert TA, Lu Y, Rebeck GW, Frangione B, Greenberg SM, Ghiso J. 2010. Iowa variant of familial Alzheimer's disease. Accumulation of posttranslationally modified $\mathrm{A} \beta \mathrm{D} 23 \mathrm{~N}$ in parenchymal and cerebrovascular amyloid deposits. Am J Pathol 176: 1841-1854.

Tomiyama T, Matsuyama S, Iso H, Umeda T, Takuma H, Ohnishi K, Ishibashi K, Teraoka R, Sakama N, Yamashita T, et al. 2010. A mouse model of amyloid $\beta$ oligomers: Their contribution to synaptic alteration, abnormal tau phosphorylation, glial activation, and neuronal loss in vivo. J Neurosci 30: 4845-4856.

Tõugu V, Karafin A, Zovo K, Chung RS, Howells C, West AK, Palumaa P. 2009. Zn(II)- and Cu(II)-induced non-fibrillar aggregates of amyloid- $\beta(1-42)$ peptide are transformed to amyloid fibrils, both spontaneously and under the influence of metal chelators. J Neurochem 110: $1784-1795$.

Tycko R, Sciarretta KL, Orgel J, Meredith SC. 2009. Evidence for novel $\beta$-sheet structures in Iowa mutant $\beta$-amyloid fibrils. Biochemistry 48: 6072-6084.

Uranga RM, Giusto NM, Salvador GA. 2010. Effect of transition metals in synaptic damage induced by amyloid beta peptide. Neuroscience 170: 381-389.

Urbanc B, Betnel M, Cruz L, Bitan G, Teplow DB. 2010. Elucidation of amyloid $\beta$-protein oligomerization mechanisms: Discrete molecular dynamics study. J Am Chem Soc 132: 4266-4280.

Utsumi M, Yamaguchi Y, Sasakawa H, Yamamoto N, Yanagisawa K, Kato K. 2009. Up-and-down topological mode of amyloid $\beta$-peptide lying on hydrophilic/hydrophobic interface of ganglioside clusters. Glycoconj J 26: 999-1006.

Villemagne VL, Perez KA, Pike KE, Kok WM, Rowe CC, White AR, Bourgeat P, Salvado O, Bedo J, Hutton CA, et al. 2010. Blood-borne amyloid- $\beta$ dimer correlates with clinical markers of Alzheimer's disease. J Neurosci 30: 6315-6322.

Walsh DM, Selkoe DJ. 2007. A $\beta$ oligomers-a decade of discovery. J Neurochem 101: 1172-1184.

Walsh DM, Lomakin A, Benedek GB, Maggio JE, Condron MM, Teplow DB. 1997. Amyloid $\beta$-protein fibrillogenesis: Detection of a protofibrillar intermediate. J Biol Chem 272: 22364-22374.

Walsh DM, Thulin E, Minogue AM, Gustavsson N, Pang E, Teplow DB, Linse S. 2009. A facile method for expression and purification of the Alzheimer's disease-associated amyloid $\beta$-peptide. FEBS J 276: 1266-1281.

Wang QM, Zhao C, Zhao J, Wang JD, Yang JC, Yu X, Zhen J. 2010. Comparative molecular dynamics study of $A \beta$ adsorption on the self-assembled monolayers. Langmuir 26: $3308-3316$.

Wei GH, Jewett AI, Shea JE. 2010. Structural diversity of dimers of the Alzheimer amyloid- $\beta(25-35)$ peptide and polymorphism of the resulting fibrils. Phys Chem Chem Phys 12: 3622-3629.

Weidemann A, Eggert S, Reinhard FB, Vogel M, Paliga K, Baier G, Masters CL, Beyreuther K, Evin G. 2002. A novel $\varepsilon$-cleavage within the transmembrane domain of the Alzheimer amyloid precursor protein demonstrates homology with Notch processing. Biochemistry 41: 2825-2835.
Welander H, Frånberg J, Graff C, Sundström E, Winblad B, Tjernberg LO. 2009. A 43 is more frequent than $A \beta 40$ in amyloid plaque cores from Alzheimer disease brains. $J$ Neurochem 110: 697-706.

Wirths O, Bethge T, Marcello A, Harmeier A, Jawhar S, Lucassen PJ, Multhaup G, Brody DL, Esparza T, Ingelsson M, et al. 2010. Pyroglutamate Abeta pathology in APP/ PS1KI mice, sporadic and familial Alzheimer's disease cases. J Neural Transm 117: 85-96.

Woltjer RL, Sonnen JA, Sokal I, Rung LG, Yang W, Kjerulf JD, Klingert D, Johnson C, Rhew I, Tsuang D, et al. 2009. Quantitation and mapping of cerebral detergentinsoluble proteins in the elderly. Brain Pathol 19: 365-374.

Wu C, Murray MM, Bernstein SL, Condron MM, Bitan G, Shea JE, Bowers MT. 2009. The structure of A $\beta 42$ Cterminal fragments probed by a combined experimental and theoretical study. J Mol Biol 387: 492-501.

Wu C, Bowers MT, Shea JE. 2010a. Molecular structures of quiescently grown and brain-derived polymorphic fibrils of the Alzheimer amyloid $A \beta_{9-40}$ peptide: $A$ comparison to agitated fibrils. PLoS Comput Biol 6: e1000693. doi: 10.1372/journal/pcbi.1000693.

Wu JW, Breydo L, Isas JM, Lee J, Kuznetsov YG, Langen R, Glabe C. 2010b. Fibrillar oligomers nucleate the oligomerization of monomeric amyloid $\beta$ but do not seed fibril formation. J Biol Chem 285: 6071-6079.

Xia WM, Yang T, Shankar G, Smith IM, Shen Y, Walsh DM, Selkoe DJ. 2009. A specific enzyme-linked immunosorbent assay for measuring $\beta$-amyloid protein oligomers in human plasma and brain tissue of patients with Alzheimer disease. Arch Neurol 66: 190-199.

Xiao Z, Wedd AG. 2010. The challenges of determining metal-protein affinities. Nat Prod Rep 27: 768-789.

Yadav A, Sonker M. 2009. Perspectives in designing antiaggregation agents as Alzheimer disease drugs. Euro J Med Chem 44: 3866-3873.

Yagi-Utsumi M, Kameda T, Yamaguchi Y, Kato K. 2010. NMR characterization of the interactions between lyso-GM1 aqueous micelles and amyloid- $\beta$. FEBS Lett 584: $831-836$.

Yamin G, Ruchala P, Teplow DB. 2009. A peptide hairpin inhibitor of amyloid $\beta$-protein oligomerization and fibrillogenesis. Biochemistry 48: 11329-11331.

Yang C, Li JY, Li Y, Zhu XL. 2009a. The effect of solvents on the conformations of Amyloid $\beta$-peptide (1-42) studied by molecular dynamics simulation. J Mol Struct: THEOCHEM 895: 1-8.

Yang C, Zhu XL, Li JY, Chen K. 2009b. Molecular dynamics simulation study on conformational behavior of $A \beta(1-$ $40)$ and $A \beta(1-42)$ in water and methanol. J Mol Struct: THEOCHEM 907: 51-56.

Yu LP, Edalji R, Harlan JE, Holzman TF, Lopez AP, Labkovsky B, Hillen H, Barghorn S, Ebert U, Richardson PL, et al. 2009. Structural characterization of a soluble amyloid $\beta$-peptide oligomer. Biochemistry 48: 18701877.

Zhang A, Qi W, Good TA, Fernandez EJ. 2009a. Structural differences between $A \beta(1-40)$ intermediate oligomers and fibrils elucidated by proteolytic fragmentation and hydrogen/deuterium exchange. Biophys J 96: 10911104. 
C.L. Masters and D.J. Selkoe

Zhang JF, Hou L, Gao XP, Guo F, Jing W, Qi JS, Qiao JT. 2009b. Amyloid $\beta$-protein differentially affects NMDA receptorand $\mathrm{GABA}_{\mathrm{A}}$ receptor-mediated currents in rat hippocampal CA1 neurons. Prog Natl Sci 19: 963-972.

Zhang L, Yu HX, Song CC, Lin XF, Chen B, Tan C, Cao GX, Wang ZW. 2009c. Expression, purification, and characterization of recombinant human $\beta$-amyloid42 peptide in Escherichia coli. Protein Expres Purif 64: 55-62.

Zhang R, Hu XY, Khant H, Ludtke SJ, Chiu W, Schmid MF, Frieden C, Lee JM. 2009d. Interprotofilament in- teractions between Alzheimer's $A \beta_{1-42}$ peptides in amyloid fibrils revealed by cryoEM. Proc Natl Acad Sci 106: 4653-4658.

Zhao JH, Liu HL, Liu YF, Lin HY, Fang HW, Ho Y, Tsai WB. 2009. Molecular dynamics simulations to investigate the aggregation behaviors of the $A \beta(17-42)$ oligomers. J Biomol Struct Dyn 26: 481-490.

Zheng J, Yu X, Wang J, Yang JC, Wang Q. 2010. Molecular modeling of two distinct triangular oligomers in amyloid $\beta$-protein. J Phys Chem B 114: 463-470. 


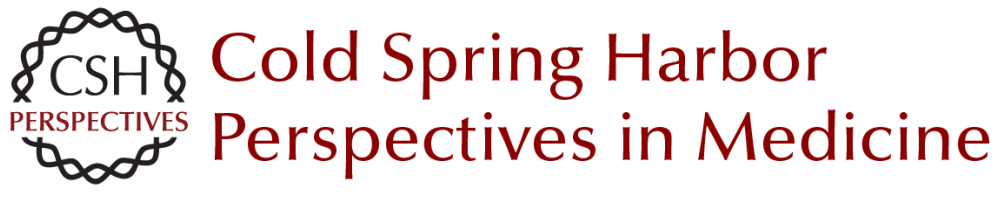

\section{Biochemistry of Amyloid $\beta$-Protein and Amyloid Deposits in Alzheimer Disease}

Colin L. Masters and Dennis J. Selkoe

Cold Spring Harb Perspect Med 2012; doi: 10.1101/cshperspect.a006262 originally published online February 21, 2012

Subject Collection The Biology of Alzheimer Disease

Animal Models of Alzheimer Disease

Frank M. LaFerla and Kim N. Green

Neurovascular Dysfunction and Faulty Amyloid $\beta$

-Peptide Clearance in Alzheimer Disease

Abhay P. Sagare, Robert D. Bell and Berislav V. Zlokovic

Treatment Strategies Targeting Amyloid $\beta$-Protein Dale Schenk, Guriqbal S. Basi and Menelas N. Pangalos

The Ubiquitin-Proteasome System and the Autophagic-Lysosomal System in Alzheimer Disease

Yasuo Ihara, Maho Morishima-Kawashima and Ralph Nixon

Neurotoxicity of Amyloid $\beta$-Protein: Synaptic and Network Dysfunction

Lennart Mucke and Dennis J. Selkoe

Proteolytic Degradation of Amyloid $\beta$-Protein

Takaomi Saido and Malcolm A. Leissring

Brain Imaging in Alzheimer Disease

Keith A. Johnson, Nick C. Fox, Reisa A. Sperling, et al.

Symptomatic and Nonamyloid/Tau Based Pharmacologic Treatment for Alzheimer Disease Paul S. Aisen, Jeffrey Cummings and Lon S. Schneider
Alzheimer Disease in 2020

David M. Holtzman, Eckhard Mandelkow and

Dennis J. Selkoe

The Genetics of Alzheimer Disease

Rudolph E. Tanzi

Fluid Biomarkers in Alzheimer Disease

Kaj Blennow, Henrik Zetterberg and Anne M. Fagan

Epidemiology of Alzheimer Disease

Richard Mayeux and Yaakov Stern

\begin{abstract}
Biochemistry and Cell Biology of Tau Protein in Neurofibrillary Degeneration

Eva-Maria Mandelkow and Eckhard Mandelkow

Biochemistry of Amyloid $\beta$-Protein and Amyloid

Deposits in Alzheimer Disease

Colin L. Masters and Dennis J. Selkoe
\end{abstract}

The Neuropsychological Profile of Alzheimer

Disease

Sandra Weintraub, Alissa H. Wicklund and David P.

Salmon

Apolipoprotein E and Apolipoprotein E Receptors: Normal Biology and Roles in Alzheimer Disease David M. Holtzman, Joachim Herz and Guojun Bu

For additional articles in this collection, see http://perspectivesinmedicine.cshlp.org/cgi/collection/ 